\title{
The city looking glass. A Philadelphia comedy, in five acts
}

Robert Montgomery Bird

Arthur Hobson Quinn

Follow this and additional works at: https://repository.upenn.edu/kislakcollectionmaterials

Part of the Dramatic Literature, Criticism and Theory Commons, and the Literature in English, North America Commons

Bird, Robert Montgomery and Quinn, Arthur Hobson, "The city looking glass. A Philadelphia comedy, in five acts" (1998). Collection Materials. 3.

https://repository.upenn.edu/kislakcollectionmaterials/3

Full text transcription of Arthur Hobson Quinn's 1933 edition of Robert Montgomery Bird's 1828 manuscript play The City Looking Glass.

This paper is posted at ScholarlyCommons. https://repository.upenn.edu/kislakcollectionmaterials/3

For more information, please contact repository@pobox.upenn.edu. 


\title{
The city looking glass. A Philadelphia comedy, in five acts
}

\author{
Abstract \\ Full text transcription of Arthur Hobson Quinn's 1933 edition of Robert Montgomery Bird's 1828 \\ manuscript play The City Looking Glass. \\ Disciplines \\ Dramatic Literature, Criticism and Theory I Literature in English, North America \\ Comments \\ Full text transcription of Arthur Hobson Quinn's 1933 edition of Robert Montgomery Bird's 1828 \\ manuscript play The City Looking Glass.
}




\section{EDITOR'S NOTE.}

The text has been collated with the original manuscript of 1828 and has been presented exactly as Bird wrote it, except for obvious errors of carelessness in punctuation or spelling. Stage directions, in which he is not consistent, have been normalized to agree with his usual practice.

DRAMATIS PERSONAE.

ROSLIN. nephew to HEAD STRONG

RAVIN. a swindling gentleman

RINGFINGER. his brother

RALEIGH. Senior

RALEIGH. Junior, his son

HEADSTRONG, father to DIANA

NATHAN NOBODY, a foundling

BOLT

CROSSBAR |> Bucks

MOSSROSE I

TOM TAFFRAIL, a sailor

O'SLASH. overseer to RALEIGH. Sr.

DIANA HEADSTRONG

EMMA GALL

MRS. GALL

An old woman; a negress; constables; servants, etc.

SCENE: Philadelphia

TIME: Two evenings and a day. The first two acts happen the first evening; the third occupies the next day; and the two last happen the second evening.

\section{PROLOGUE TO THE CITY LOOKING GLASS.}

In ancient days, mankind, dissatisfied

With all the gifts that royal glove supplied, Went on their marrow-bones, and begged permission His ears to trouble with a new petition.

Whey vowed the presents of the Thunderer King 
Were, with his godship's leave, not quite the thing; One half the world, (he had made 'em so perverse,) What t'other called a blessing, thought a curse; (Their sages had this aphorism set eyes on, That "What is one Man's meat, 's another's poison;") Wherefore they begged, an' he should hear their call, Some gift might be agreeable to all. Jove cogitated: This is hard, quota he; In what thing will these clamorous knaves agree? Whatever their necessities required I gave, yet something more is still desired. Vain fools! - What! Vanity? Ay, that will pass:And prove presented them a Looking Glass! Most glorious gift of condescending grace!

Where each one saw that pleasant thing, his face!

Oh! that the Looking Glass we show to night, With the same spell could give the same delight! And, where some pleasing lineament is shown, What each might softly whisper, That's my own! And where an uglier product of our labour, With the same readiness, say, That's my neighbour! No portraits here of ego, tu, nor ille:Such things, we are told, are criminal and silly:So, not to increase our follies and our crimes, We've only made a 'mirror for the times'; Where ye may look, and see such knaves and asses As, we hope, can't be seen in your own glasses, Playing before ye certain tricks and capers, Such as you look for daily in the papers.

Our ware's domestic; if his only clever, Uncle Sam and his factories forever! If not, pray say so:-there is yet a sure hope, We'll get our wares, as heretofore, of Europe!

ACT ONE.

SCENE 1. A garret in MRS. GALL'S house. (Enter RAVIN and RINGFINGER.

RAV. Is the old hag abed? 
RING. Ay: don't you hear her snore?

RAV. And Emma? where is she?

RING. Saying her prayers, or crying in a corner.

RAV. Zounds! Jack, your gentility sits as clumsily on you as your new clothes Pr'ythee, straighten yourself in the shoulders, and keep your hands out of your pockets. Only fancy yourself a gentleman, and you are one; for the character, like that of a poet, is oftener established by conceit than by natural privilege.

RING. Gogs! and I am a gentleman after a sort; but it has been so long since I've been in company, that I've almost forgot my manners. And look ye, Ben, Penitentiary uniform and stone-cutting will spoil any one's manners.

RAV. I have introduced you to a circle, where, to be as genteel as the rest, it is only necessary for you to dress well, to drink deeply, to be knowing with the ball and pasteboard, and to swear abominably. Follow them in their frolics, invite them to the tavern, let them be often drunk at your expense, and they will suffer themselves to be gulled out of sheer gratitude. You will find Bolt, the lawyer, an excellent introduction to all the rakes and profligates in town: therefore be tender of his purse. Keep up the Doctor; the character is respectable, and will be an excuse for want of manners. You have one ill habit, however, which you must get rid of,-_pocket practice, pocket practice!

RING. I must tell you, Ben, that is my forte. I am pretty considerable at cutting the copper, tracing signatures, and shuffling the pack; but picking pockets is my forte, and all New York can't show my equal.

RAV. Drop it, however, or drop me: It is a damned low vice, and will ruin you yet.

RING. Yes, if I handle it as clumsily as you do your cues and cards. I suppose you've been sucked dry again?

RAV. As dry as a fool's wit, and by a fool's wit too. There's an ass of a sailor, in citizen's clothes, that gets into all the decent hell-holes in town; and he 
makes as free cargoes of my pockets, as you did of your neighbours' before you went to grind marble at Auburn: And the fool won't deal in domestics neither; nothing but genuine prints or hard coin will serve his purpose. And tonight he has plucked and drawn me like a partridge.

RING. Well, dammee, here's that'll salve your conscience.

RAV. Ha! what the devil's this?

RING. That's a genuine figure. I bought it of an engraver's 'prentice. Vignette, margin, firm-signature, all complete: was to've been sent to bank tomorrow.

RAV. Proof! the rollers! the inkball! ( Whey open a chest, take out the rollers, and strike off an impression.) Glorious! glorious! glorious, my boy! Why 'tis a Twenty! a fair, sweet-faced, virgin Twenty! Why Garket! Ringfinger! Jack! brother! what did you give for this?

RING. Fifty.

RAV. Genuine.

RING. Counterfeit.

RAV. Ha, ha, ha! Excellent! glorious! Honour among thieves! This is a God-send: our old stock was poor in the market, advertised as trash in every newspaper. This shall buy Diana and all her household; and Emma, excellent little virtue! I'll clothe her with gold and jewels, I'll-

RING. Pshaw! you'll spend freely, I know that well enough. But how comes on affairs with the fiftythousander? How's your wound?

RAV. Where? in my heart?

RING. Rot your heart.-Your arm?

RAV. Healed by the first intention, doctor,-ha, ha, ha! 
O. curse you, why didn't you brain the scoundrel that rescued her from us? Lord, lord! when you shot me, and I jumped, a dead man, on the ground, I had nearly broken my back; I was never so awfully bemauled!

RING. Gadswogs! nor I. I was just about to drag her from the gig, when the infernal young dog came slapover my sconce with his horn-headed bamboo:-smacked his whip, cried out to the people approaching, Secure the villain, and was out of sight in a twinkling. Now, Ben, I should like to know what you meant with this freak; for, dammee, if I ever rightly understood it.

RAV. No! Why the jade didn't love me half fast enough; and I intended by this contrivance to receive a wound while protecting her, (think of that! wounded for her sake! ha, ha!) and then, while you were carrying her off, I intended to rise up, reanimated, invigorated by a sense of her danger, pursue you, beat you horribly, and rescue her; and then I intended, while she was dying of love and gratitude, to marry her a week after.

RING. Ay, but I hear this chap that knocked me on the head, has been cutting thereabouts, while you was doctoring your wound.

RAV. Never fear. I intend to be very convalescent, and visit them tonight; when I will contrive something will blow the impudent fellow to the devil. My wit never failed me. There I had my two charmers, Diana and Emma, both under one roof; I contrived to separate them, for fear they would make confidants of one another: and now Diana would as soon fondle a toad as speak to poor Emma. Then there was Diana's cousin, Roslin; the young ass was falling in love with Emma; I whispered her mother's name and occupation, and they turned the poor devil out of doors; while Roslin went into the country to hide his sorrows and write poetry.

RING. And how did Emma get into such decent company?

RAV. 'Cause she and Diana were schoolmates. Old Gall was educating her decently, and paying her expenses by proxy; so the poor thing never knew, till I blowed them all, what an infamous old hag she had for a mother. 
RING. Well, Ben, since you are in a talking humour, tell me how it is you have such power over old Gall, as to make her do just what you please?

RAV. By knowing a secret would send her to the Penitentiary.

RING. Humph! And what do you mean to do with her daughter?

RAV. Who? Emma?-Marry her.

RING. I can't see what you want with so many wives. She has no money.

RAV. I am laying plans to marry a dozen times for money; and I intend to try it once for love.

RING. Women have been the ruination of many an honest man-

RAV. Shut up the box!

(Enter MRS. GALL.

GALL . Mr. Ringfinger-

RAV. Devils! Shut the box! put out the light!

GALL. O Mr. Ravin, is that you? I thought you were sick abed.

RAV. No, old woman, it isn't me. I am the devil: get out of my way, or I'll tear you.

GALL. Lord! Mr. Ravin, you are a comical to scare a poor body so.

RAV. What do you want here? Begone!

GALL. Lord! such a fuss! there's a gentleman wants Mr. Ringfinger.

RAV. And how dare you come in here without knocking? Out with you, old devil; get you to bed and sleep. 
GALL. Old devil! old dev-

RAV. Out with you, beldam!

GALL. Old devil!_Sir, there's a law for slander.

RAV. And another for kidnapping. Get you gone, or I'll send you to the Penitentiary.

GALL. For mercy, Mr. Garket!

RAV. Ravin, old woman, Ravin!

GALL. Dear Mr. Ravin, I didn't mean to offend you.

RING. Not she; she daren't: Therefore only hang her.

RAV. All safe? Ha, ha, ha! mother Gall! mother Gall! Why I would not send that delightful old bag of bones to jail for all the world.

GALL. Indeed, Mr. Ravin, I never thought you could have the heart.

RAV. Not I: keep your own secret; mine shall not trouble you. Go to bed.-Where's Emma?

GALL. She is below listening to some music in the street.

RAV. Come get along with you. Take care of the figure, the genuine.

(Exeunt RAVIN and GALL.

RING. I would I had the wit of that rascal, my elder it brother. I am sure he is a greater rogue than myself, and yet he has never seen the inside of a penitentiary. $\mathrm{He}$ is a gentleman too, that's when it suits his humour; he can make love and marry who he pleases, the richest and handsomest wenches in the land, while I could never get a wife worth a dollar. I was always taken in,--they made such a fool of me in the solitary cells. (Exit.

SCENE 2. A room in the same. 


\section{(Enter RAVIN and EMMA GALL.}

RAV. Indeed, my sweet Emma, I must be angry with you. Youth like yours should seek its pillow early; and I value those blossoming cheeks too much to allow them to be blanched by unnecessary vigilance.

EM. Sir, you are very good;--but I cannot sleep.

RAV. Fy! when a young maiden cannot sleep, the world says she is in love.

EM. The world says also, that love makes one happy, does it not?

RAV. It does. Love is the only security of happiness in this world; and they who are in love, are always happy.

EM. Then I am not in love, for I am not happy.

RAV. Fy, fy! not happy! Did nature give you this excellent beauty to become a sacrifice to sorrow?

EM. Sir, you are familiar with my condition. The world looks on me with scorn: who can feel themselves despised, and yet call themselves happy? They who have been my friends desert, and they who are my enemies detest me;--and they are justified, for although innocence stands my friend, appearances do not.

RAV. And why should the world scorn you?

EM. Because I am closely connected with that which the world abhors. You, Sir, who have honest and estimable kinsmen, whose condition has placed you beyond suspicion, and whose sex has mounted you above insult,you cannot feel the unhappiness of my condition.

RAV. Upon my soul, you do me much honour. Condition and suspicion! Sex and insult! Humph!_-You may be unhappy in your connexions; but they who are free from crime, have no excuse for being miserable. The world may wrong you, but your own heart should not.

EM. And it does not. 
RAV. Come, I must make you blush, to make you content. The world scorns you, because it admires you. 'Tis a paradoxical world, an envious monster, whose detestation is its greatest praise. Had you been born lame and ugly, detraction had given way to commendation. But nature made you fair, gave you eyes that will one day set men mad with love, and women mad with jealousy; she furnished you with a heavenly face, that it might expose devilish hearts; - and were I a woman, I should poison you or myself, out of pure envy. Wicked people abhor you, because you are yourself good; good people hate you, because they fear your power of making them bad. You are a tempter, Emma; and all saints that look on you must bethink them of their paternosters. You have no friends?-You are too fair to have friends.

EM. You speak this to divert me, sir; and I am grateful for your kindness, though it come through the medium of satire.

RAV. Very true notwithstanding. I tell you, you are envied; and you must not blame nature for making you fair, nor me for telling you, you are so. Come, cast away these unbecoming shadows, and place this jewel around a neck ten times more beautiful and precious. Now don't be obstinate, and mortify me by a refusal.

EM. These are pearls.

RAV. They are emblems of purity.

EM. When the world will allow my fame to be as spotless, I will accept them.-I cannot take them, sir: My mother supplies me with all necessary apparel; and indigence should not become ridiculous with ornament. (Exit.

RAV. Excellent little morality!—Curse me, but I should engage some friend under oath to cut my throat the moment I wronged her; but that would be, to make the best of it, very foolishly wronging myself. I can't tell how it is, but she makes me feel very modest and very civil whenever I speak to her. I intended to have made love to her, and, faith, I had no sooner looked upon her, than I became as Platonic as a potato. I must drink wine the next time, and then I shall be as amorous as an Irishman. I must have her, one way or other; for I have 
that talismanic knowledge about me, which will make the poor, despised, avoided Emma Gall, the mistress of a certain Virginia plantation, with its tobacco fields, slaves, cornhouses, and other certain messuages to be therein specified,- - that is, in her father's will.-But my wife, my wife! and my Diana, my Diana! The devil take Diana, so I take her fortune; and the devil take my wife, for he has already got her's. Now will I to my adorable Diana, be suddenly a gentleman, a languishing lover,- - with a scarf round my arm, to admonish her eyes, while my tongue persuades her ears, that both heart and arm were mutilated in her service, while indeed one is as sound as the other.

(Exit.

SCENE 3. The street before the theatre. (Enter ROSLIN and NATHAN NOBODY.

NATH. Hilloah there, mister, if you're a gentleman.

ROS. And if I be not a gentleman, what then?

NATH. Why then, Hilloah you-sir-if you've got a fip to spare, I'll discount it for you.

ROS. Hang you, young villain, what do you mean?

NATH. Why here, good gentleman, here's one poor copper; 'tis all I have earned to day. So, if you'll deliver me a fip, I'll change it, that's all.

ROS. You are a wonderful impudent beggar.

NATH. A beggar! Not I: I am a discountant, a travailing bank. I had rather be a thief than a beggar any day.

ROS. So it seems. Who taught you this effrontery?

NATH. My mother.

ROS. And who was she?

NATH. A willow basket. Sir, I was brought forth not of a woman, but of a willow basket; I was gotten, if not begotten, in the gutter, for there the watchman found 
me.

ROS. You are a merry rogue.

NATH. And like many an other merry rogue, must, for lack of sixpence, whistle for my supper.—I am half starved already.

ROS. Take it, poor fellow.

NATH. I thank you, sir, and hope you will sup to night as heartily as myself.

ROS. Stay, lad;-I pity you.

NATH. Six and a quarter cents.

ROS. Truly that is but poor pity. Here's half a dollar for you. Could I think you were not a worthless vagabond, I might do something for you.

NATH. Try me.

ROS. Who will recommend you?

NATH. Nobody.

ROS. That's a recommendation nobody will take.

NATH. Sir, when I say Nobody, I mean somebody; for I am called Nobody myself, that is, Nathan Nobody, at your service: And nobody will say, Nathan Nobody here is not Nathan Somebody.

ROS. Why boy, who was your father?

NATH. Nobody; no one claimed me: and therefore, though the Guardians called me Nathan Basket,(which was wrong, to call any one after his mother;) and though some people called me Nathan Smith, (which was equal to Nathan Nobody, and after all was a name I had no title to;) I thought the best way to save trouble, would be to take my father's name, or, what's the same thing, nobody's name: and therefore I am called Nathan Nobody.

ROS. Nathan Nobody! Ha, ha, ha! You are a wag. 
NATH. SO people say. I make a half starved living by it: but wagging one's wit, does not always enable one to wag one's tongue or teeth; and smelling out a joke is not always the way of smelling out a dinner. The business of a wit is the starvingest profession in the country.

ROS. Ay; and the people won't always laugh neither.

NATH. That would not vex me. When people won't laugh at my jokes, I suppose they are too stupid to understand them. The best service my name does me, is, that, like charity, it covers a multitude of faults: for, do what mischief I may, that mischief is always done by Nobody.

ROS. Ha, ha, ha!_-Are you honest?

NATH. Why do you ask?

ROS. I'll give you food and shelter, make a great man of you, if you be.

NATH. Why then I am.

ROS. Will you be my servant, my squire, my page?

NATH. With all my heart, if you are not aristocratical.

ROS. And why not, if I am aristocratical?

NATH. Because I hate an American aristocrat as much as I hate an English travailing lord, or a French travelling count. They brag, talk of their ancestors, and show their coats of arms; which gives an honest man reason to suppose, that they have formerly had in the family more arms than ears; that their titles were registered in a jail book; that their family house was a dunghill, and their tree of genealogy a gallows.

ROS. A very republican spirit! Your observation should have shewn you that, in this land, no one inveighs against aristocracy, unless he is poor. Give him a fortune, and he finds no rank above him to rail at. Properly understood, aristocracy means wealth, and republicanism poverty; and there is always a natural enmity between the poor and the rich.-Can you do 
any thing besides joking and railing?

NATH. I can thresh your jacket, and dust your coat; I can ring your bell, say your prayers, and write your love-letters.

ROS. Indeed!

NATH. I can dun your debtors, lie to your creditors, speak evil of your enemies, and slander you with much praise.

ROS. Your wisdom is beyond your years and condition. What wages will you have?

NATH. A new suit when my old one decays, which may be monthly; pocket money when I want it, which must be daily; and a theatre ticket when I like it, which shall be nightly.

ROS. A theatre ticket! What would you do at the theatre?

NATH. Learn wisdom. Sir, I have learned much at the theatre; I have learned several speeches, which I can put you to sleep with; several songs, which I can keep you awake with; and above all, I have learned how a wise fellow can climb on the shoulders of fools. One of the actors, a good sort of a soul when the audience didn't hiss him, taught me a doleful ditty that I sometimes chant to such people as will give a dollar to hear a French concert, but will recommend a beggar to the workhouse. (Sings)

Sad and lone, the foundling boy Treads the path misfortune gives, Seeking, still unfound, the joy In a parent's arms that lives. Cast upon the world's wide sea, Rudely tost by wind and wave, Where's the haven waits for thee? Foundling boy, 'tis in the grave!

Few but meet a parent's love, Smiles of kinsmen kind and good, Hearts to shelter and approve, Bound by ties of love and blood. 
Parents, kinsmen, where are they?

Sighs the roving foundling son:

Dry thy tears, and haste away,

Weary foundling, thou hast none!

It is too melancholic, but it suits some.

ROS. Follow me then-

(Enter RALEIGH, JR.

RAL.JR. Sir, what do you mean? You have trod on my toe.

NATH. Sir, are you gouty?

RAL.JR. Sir, I ask you again, what do you mean?

ROS. I mean to say, How d'ye do, old playmate?

RAL.JR. Roslin!-My most excellent friend, and memento of college fancies!—Faith, I was near boxing your ears!

NATH. You could not do it as effectually as the Grand Turk; he boxes them by thousands, as one boxes codfish, packs them in Greece, and-there the pun ends - unless one might say, he eats them in Turkey.

RAL.JR. Who is this impudent little raggamuffin at your heels?

ROS. My page, Mr. Raleigh, my errant page. This is a heaven-send, a dewdrop, a sprig of nettle-a stinging thing - that grew in the gutter, and was born of a willow basket.

RAL.JR. And is that his livery?

ROS. I shall equip him like a lord, - a republican lord. At present though, my Southern madcap, what are you doing in Philadelphia?

RAL.JR. Making love.

ROS. What! to one of our bonny young quakers? our antislavery moralists? She will ruin you. 
RAL.JR. By manumitting my bondsmen, or stiff- starching my children? Fear me not. I am heterodox in my passion, but orthodox in my damsel. I tell you, Roslin, you may have your pages and your squires; but I am the genuine knight, the gallant errant, the succourer of distressed ladies.

ROS. Indeed, Raleigh, I never doubted it. I have seen you mortified for your errantry, and beaten for your gallantry.

RAL.JR. Pr'ythee be not cynical. I am the luckiest dog in the world: I have relieved a woman from bondage, and ordained her to captivity; I have taken her from the springes, to load her with chains.

ROS. Honourable ones, Raleigh?

RAL.JR. Listen to me, and laugh not, for I speak matrimonially. A few days ago, as I was sauntering on, or rather about, the Ridge Road, I surprised a villain who had attacked a gig, shot the gentleman, and was laying his accursed paws on the lady, when I-merely thus - went across his caput with a trusty bamboo, knocked him senseless, left him and the gentleman to some people collecting, - sprang into the gig, and being told by the half crazed damsel that her father was before in his carriage, drove away with her in triumph. Ever since which it has been remarked that we are desperately in love with one another.

ROS. Excellently done. What became of the gentleman?

RAL.JR. Who?

ROS. He that was shot.

RAL.JR. Why I had hoped they had buried him. But it seems he was only scratched or scared.

ROS. Is he a rival?

RAL.JR. Yes.

ROS. What will you do with him? 
RAL.JR. Refer him elsewhere. If that don't satisfy him, I'll horsewhip him; and if he is still refractory, I'll shoot him.

ROS. That will be despatching him with a vengeance. Now, what is the lady's name?

RAL.JR . Miss Diana Headstrong.

ROS. Zounds! she is my own cousin!

RAL.JR. I wish with all my heart she were your sister; or, what's the same thing, I wish I had a sister to give you. I had one once, but she was drowned while an infant. But, apropos, how fares the little angel you wrote about, some six months ago? the mysterious tragedy queen, you made so much fuss about? how fares she?

ROS. Heaven knows!

RAL.JR. And don't you? You are as gloomy on the sudden as an autumn day!

ROS. Never lay faith in the human face, Raleigh. That girl, whom I imagined the offspring of something superhuman; that gentle, beautiful and melancholy girl, whose veins, I fancied, contained the blood of queens!-

RAL.JR. Ay, that's the way you wrote about her.

ROS. The mystery was revealed, and she was suddenly metamorphosed into the daughter of-a public bawd!

RAL.JR. By Jupiter! that was a metamorphosis! Curse her impudence, how did she get into decent society? I hope they tarred and feathered her! What has become of her?

ROS. I know not; I have not seen nor heard of her since. But to leave a disagreeable subject: the wounded gentleman, whom you so civilly left to take care of himself, must have been Mr. Ravin, a wealthy Yankee, who, as I am informed, is a man of fine address and talents, and a great favourite with my uncle and Diana. I have been several months in the country waiting upon 
an invalid mother; but even there the rumour reached me, that there was to be a match struck between them.

RAL. That was a lying rumour, Roslin.

ROS. I am glad to hear it.-Come along with me. I have but this day arrived in town, and shall keep bachelor's hall for a week or two. Come along.

RAL.JR. Why Diana is not there?

ROS. No indeed.

RAL.JR. And how the devil could I go anywhere, where Diana is not? Good night. I'll call on you tomorrow. (Exit.

ROS. Boy, did you observe that gentleman?

NATH. Yes sir: he is in love.

ROS. Can you tell me what love is?

NATH. No sir, but I can tell you what it is like and -it matrimony too.

ROS. So.

NATH. Love is like a fever and ague, being a thing of chills and heats, hot and cold; and is only to be cured by the sweat, jealousy, or the vomit, matrimony: and matrimony itself is like a brass pot with a hole in the bottom, filled with water, and set to boil upon the embers of love, which it soon puts out. Love is, like a doctor, a breeder of diseases; and, like a lawyer, a provoker of damages. It is the foe of strong heads, and the friend of strong liquors; for the one it runs from, and the other it sets running: strong heads as naturally abhorring love, as weak ones do strong drink. Love is like a caterpillar, which changes to the butterfly matrimony, and then flies from the shell that warmed it. Love is like water, which a short season freezes into the ice, matrimony: when boiling into love, it is a scalding draught; when frozen into matrimony, let him that would slide thereon, look to his heels, for 'tis a slippery foundation. Love is a mirror where men appear 
like angels; matrimony is a great looking glass<?> wherein men are changed to monsters; some appearing oxen, and others apes; and those that look most like men, are commonly chained like galley slaves or hoppered like horses; for to be in love is to be in captivity; and for a man to be in love matrimonial, is to be tied to a bed post with a garter, or to a beam with a halter.

ROS. Hang you, imp, did you learn this of the theatre too?

NATH. No, sir, I learned that of the newspapers, where it may be seen every day under the heads, Conjugal Felicity, Elopements Extraordinary, Suits for Breach of Promise, and trials for Crim. Con. In the mean time,

sir, as you have made me your squire,-_('d rather be called that than servant) and are therefore bound to take care of me, I must inform you that necessity is not only a whetter of wit, but a whetter of appetite also.

ROS. Come along then. you shall be fed and clothed; and it will be your own fault, if you are not a great man one day.

NATH. Yes, I shall be a newspaper editor or a play actor no doubt.

(Exeunt.

SCENE 4. A parlour in HEADSTRONG'S house. (Enter HEADSTRONG, DIANA, and RALEIGH, JR.

HEAD. And so, Mr. Raleigh, you don't know Mr. Ravin?

RAL.JR. I have not that honour, Mr. Headstrong

HEAD. Why then, my excellent dear boy, you shall have that honour to night.

DIAN. Tonight! Bless me, pa, I thought Mr. Ravin was secure for another week. 
HEAD. How! secured for another week! Secured! Is this your gratitude? Is it thus you express your thanks to the man whose blood was shed in your defence?

DIAN. My dear father, I am the most grateful woman alive; and it is my very tender regard for Mr. Ravin's health, that makes me dissatisfied with his premature visits. - I beg Mr. Raleigh's pardon for appearing to neglect his. I should certainly have expressed a similar anxiety; but-

HEAD. (Aside.) Good. I fear he grows particular. I like the boy well, but discourage him.

DIAN. Fear me not, dear sir.

HEAD. we are pledged in honour to Mr. Ravin. Be civil, but distant-

(Exit.

DIAN. I will, sir.-Mr. Raleigh, my father was saying, I was rude in not expressing my anxiety for your health.

RAL.JR. Be not uneasy. The indifference which keeps me at your side, is more agreeable than the solicitude that drives me away.

DIAN. A false construction and a vain one.

RAL.JR. Pr'ythee now, be not coquettish, or I shall be tantalizing. I know you are terribly fond of me.

DIAN. we are told that knowledge is vanity and vexation; and we know that vanity is always vexatious.

RAL.JR. Fy! while your father is ever eager to impress me with a sense of the high value you set on this Ravin, are you not always busy to persuade me you care not a copper for him?

DIAN. You do not seem willing to understand the relation in which Mr. Ravin stands to my father and myself.

RAL.JR. Perfectly. Your father was anxious to make him your husband; and as you did not happen to know your own 
mind, or mine, some time since, you found nothing odious enough in his addresses to make you entirely reject them. But now, enter myself upon the arena, and things are changed. I tell you, you hate, despise and abhor him, and find my little finger more amiable than his whole body. Be honest and confess it.

DIAN. Sir, are you in love with me?

RAL.JR. Immeasurably.

DIAN. And is this the Virginia mode of wooing?

RAL.JR. It is my own. I could kneel, sigh, poetize, and serenade with the best of 'em, if I would; could talk softly, lie lovingly, and even weep upon occasion; yea, o I could sing too, if I were so minded, verses of my own manufacture, as regularly cut and set as the teeth of a saw, and with a voice as soul-searching as the file with which the saw is set: I could do this, like other people; but it is ridiculous: and the only wholesome way of wooing, as of betraying, is with a kiss-thus.

(Enter HEADSTRONG and RAVIN.

HEAD. |

RAV. I

|>Humph!

DIAN. The impudent wretch! I'll never forgive him.

RAV. My dear Miss Headstrong, has your memory paid me the ill compliment-

DIAN. Mr. Ravin! I beg your pardon. I am excessively glad to see you. How is your arm?-You are pale, very pale: I declare you look very ill. you must have lost much blood. I am afraid you were incautious, to expose yourself so soon. you are very weak.

RAV. Every word of solicitude you express is an invigorating medicine to me.-Damn her solicitude.-A kiss!- I have fooled her off my hands with a vengeance.

HEAD. Mr. Ravin, let me have the pleasure of introducing you to Mr. Raleigh. 
RAV. Mr., mister who?

HEAD. Mr. Raleigh.—Sir, you are ill! Do you feel fainty?

RAV. Mr. Raleigh!-Not a whit, not a whit. My wound often affects me thus.-Mr. Raleigh? of what state?

HEAD. Virginia. Son of Washington Raleigh of Richmond.

RAV. So!- - The devil is walking abroad at last; and Ravin must take care of Garket.- If I could but make this old fool suspicious.-Hum.-Introduce me, sir, if you please.

HEAD. Mr. Raleigh, I have the pleasure of making you acquainted with Mr. Ravin, of New Hampshire.

RAV. Sir, I am happy in the acquaintance of a gentleman so instrumental in the salvation of this lady.

RAL.JR. Very much at your service, sir.

RAV. Sir, may I take the liberty of asking if you are not related to a certain Mr. Benjamin Garket of-

RAL.JR. Hark you, sir, if you mean to be impertinent, six steps after me will bring you to a more convenient place.

(Exit.

DIAN. Mr. Raleigh! Francis! Heavens! what an insolent madcap! (Exit.

RAV. So!

HEAD. Zounds, sir, what's the meaning of all this?

RAV. Sir,-Mr. Headstrong,- - do you know who that man is?

HEAD. Who he is? Why, Mr. Raleigh, son of Washington Raleigh-Why do you shake your head?

RAV. Did you ever hear the name of Garket?

HEAD. Garket, Garket? Wasn't that the man that robbed 
the bank in Virginia?

RAV. Benjamin Garket, Esq., take him for all in all, was the completest rascal ever Virginia produced; and that is saying something for him. He was an officer in a certain bank in that state, which he was wont to embezzle of many sums of money,--very often forging draughts, which were offered by men in his employ, and accepted by himself; till at last his treachery was discovered, and he fled. He was a man of genteel birth, and was married to the niece of Washington Raleigh, Esq.,- - to this young man's cousin, if he be Washington Raleigh's son.

HEAD. If he be Washington Raleigh's son! Why who the devil is he, if he is not Washington Raleigh's son?

RAV. I mistrust him. Have an eye to him.

HEAD. Who is he, I say?

RAV. Did you observe his rage, when I mentioned Garket's name to him? I mistrust him mightily. Beware of him.

HEAD. Devils! Who is he? Is he an impostor?

RAV. I fear so: Garket was an impostor.

HEAD. Heaven and Earth! Do you think it is Garket?

RAV. Ay—But I may be wrong, I may mistake.

HEAD. Indeed you do. Garket must be an older man.

RAV. I was told by one who had known him, that he was a very youthful, quite a boyish looking fellow, under thirty.-Did you observe how he started, how he coloured, how he pretended to be insulted, and decamped, when I pronounced his name?

HEAD. I did. By the lord, I'll cane him for his impudence. I'll have him committed, the rascal, the frontless villain! I'll send for the constable.

RAV. Be not precipitate. Recollect we have no proof. Rest awhile, till I can write to Virginia for means of 
identifying him.

HEAD. He'll escape.

RAV. Not he: he is the boldest dog in the world. Bold did I say? He must have more impudence than a Philadelphia negro, or a New York pickpocket, to come into your house, and make love to your daughter.

HEAD. Make love to my daughter! The infernal wretch! I'll shoot him!-But he saved her from ruffians.

RAV. A stratagem. Garket is a horrible libertine, and has married several rich women, whom he deceived, robbed, and forsook.

HEAD. The outrageous villain!

RAV. I doubt this was a scheme of his, to introduce himself, and look heroical. How easily might he not have stationed one of his gang in the hedge, and then have saved her from him?

HEAD. Indeed he might, the prodigious villain!

RAV I believe this arm of mine must witness against him.

HEAD. Horrible! I suspect him strongly. Let's commit him.

RAV. No; let us have proof, proof, sir.-Do you not fear your daughter has withdrawn her affection from me to place it upon him?

HEAD. Lord, lord! I would cut my throat first.

RAV. Yet she suffered his odious kisses. Did you mark as we entered?

HEAD. Damnable! I'll hang, stab, poison, murder, assassinate him. you shall have her, Mr. Ravin; she shall marry you to morrow; if she refuse, I will make over all I am worth in the world to the different charities, die the next day, and leave her a beggar.

RAV. Indeed sir, I fear I am supplanted in her 
affections.-

HEAD. Love a felon, a rascal, a bank-robber, a bigamist, polygamist, a goat, a bear, an ass! You shall have her, I say. Come along-O Damnable! horrible!

(Exit.

RAV. This is the most combustible piece of tinder, this old fool, that I ever set eyes on. He catches fire like a saltpetre rag, and trains as fast and as furiously as gunpowder. I have seen many credulous fishes; but he bites as readily at a lie, as a shark at a roasted brick; and ten to one, he will presently find the bait both too hot and too hard for digestion. Let Diana inherit but half her father's credulity, his gullability, she will to morrow or next day be Mrs. Diana Ravin at my service, and a week after, Miss Diana Headstrong again, at any body's service. And then for Emma, lovely little fool,--plying myself with brandy that I may the better ply her with love.-Hum —a bold man might marry her, assume another name, cultivate his whiskers, march off to Virginia, claim her portion, and then march off to the devil. 'S death, if I succeed fairly with both these wenches, I shall have cause to remember Philadelphia with gratitude for ever. I have commenced in its streets an odd comedy, the chief ingredients of which are love and counterfeit money; and while the ladies are willing to receive the former, I am sure the gentlemen will not boggle at the latter. (Exit.

ACT TWO.

SCENE 1. A room in ROSLIN'S house.

(Enter ROSLIN and RALEIGH.

ROS. If this be love, Frank, it is an unsociable monster. Come, I am dull,-—you must drink with me.

RAL.JR. Don't tempt me. Love is a water-drinker.

ROS. I have known you an admirer of the flagon; and I 
have heard you say that a wench without wine was as ridiculous as a purse without money.

RAL.JR. That was in my college days, when my chamber was a conventicle, my light a bright eye, my candlestick a wine bottle, and my book of prayers a pack of cards; when a college chum at night made a washer woman's daughter in the morning; and when a friend's cloak often concealed an enemy's petticoat. Pr'ythee do not tempt me with the recollection of past follies; for wisdom and I have but lately shaken hands, and are not yet fast friends. Don't tempt me.

ROS. Not from your true allegiance, not from Diana, I hope.

RAL.JR. Humph.-Now you remind me of other affairs. Pray tell me, do you know among your friends a certain scoundrel, called Robert Ravin of New Hampshire?

ROS. My acquaintance is limited among scoundrels.

RAL.JR. Say not so. you are a man of worldly knowledge; and to know the world is to be familiar with scoundrels. Men's hearts are like oysters; you may open a thousand, before you find one containing the pearl, honesty.-But of this Robert Ravin.

ROS. He is your rival.

RAL.JR. Yes; and I have a double cause for shooting him; for as I am a sinner, the villain had the insolence to remind me of my connexion with Benjamin Garket, (as arrant a swindler as ever lived) who by marrying my cousin, has drawn my father's family into some share of his infamy. The dog went into Virginia after I was sent to the North to be schooled, so that I never got sight of his ugly face; and, in fact, he was so quick a knave, that in a very few years, he had fobbed my father, who treated him to a very worthy and wealthy wife, and indeed every body else that had more money than wisdom; robbed a bank; deserted a wife; and set sail for England, where, I hope, he has been hanged a year ago. Sir, knavery runs in that man's blood: I am told he had a brother, as great a rogue as himself, who is at present in the New York State Prison, or who has been 
there.

ROS. Perhaps Mr. Ravin meant you no insult.

RAL.JR. Then he must be afoot; for to remind a gentleman of his poor or dishonest relations, is an indication of either impertinence or fatuity. - I invited the saucy knave to follow me; when, by the lord, though I meant him the civility to pull his nose, he followed me not. I called at his hotel, but he was invisible.-But after all, he is a comical dog, a lad of some mettle, given to fleshly frailties, like a certain person, that shall be nameless, in his college days; and after I have beaten him, and had one more look at his mistress, I may forgive him.

ROS. His mistress!

RAL.JR. Ay: Think of it: a man with a mistress rivalling a man without one! He has some mettle, that's clear.

ROS. Where did you see her?

RAL.JR. I was passing by her quarters, just as Ravin came from the door. I recollected the rascal the moment I met him again at Headstrong's, and felt strongly tempted to kick him down stairs. He is convalescing too, and passes for an invalid. He has some taste though. The wench looked from the window as I passed: 'twas just sunset. I caught a view of her visage; it was devilish pretty, ay, amazingly handsome,- - so that I was struck dumb, and stood before the window like an ass, and absolutely for three quarters of a minute, forgot there was such a being in the world as Diana! Then I turned to a cobbler, and asked him, who dwelt there; A bitter woman, said he, for her name is Gall.

ROS. Ha! Gall? He was a foul-mouthed liar!

RAL.JR. Whose cat's broke her leg now?

ROS. You must show me the house.

RAL.JR. No poaching.

ROS. Fear not. I have another object in view. 
RAL.JR. What's that?

ROS. Why should you ask? Does not the man make pretensions to my cousin's hand? and should not I examine into those pretensions? I will but satisfy my suspicion; and therefore-

RAL.JR. Therefore-Humph!

ROS. Come, show me the place.

RAL.JR. I can t.

ROS. I beseech you, show me.

RAL.JR. I've changed my mind.

ROS. Sir, you must.

RAL.JR. I won't.

ROS. Are you serious?

RAL.JR. This fellow, sir, is my rival, perhaps my enemy; but he shall be treated honourably, and conquered by no tale-bearing: And therefore you may look for this damsel yourself, for dammee if I tell you a word more about her.

(Exit.

ROS. Should this be true, what a miserable fool am I F Why should I care or think about her? Was not the torture of the first discovery,- - of her base origin enough? Oh heaven! but she was innocent then, and her only crime was her vile birth, and viler mother. And now, - but it is false! it cannot be; I will prove it false: She may be wretched and slandered; she cannot be so lost and depraved.

(Exit.

SCENE 2. A room in HEADSTRONG'S house. (Enter HEADSTRONG and DIANA. 
HEAD. Now, daughter, what do you think of him?

DIAN. He is a villain.

HEAD. Think of it! This is the second time within the last half year, we have been so deceived. Once by that girl, that Emma Gall, whom you took so much notice of: and she to turn out the daughter of a-a very bad woman! and so near catching our cousin Roslin: I believe he was half in love with her. The wickedness of this world!

DIAN. Yes sir, and it may appear hereafter that one has been as much slandered as the other.

HEAD . Slandered!-His consummate impudence!

DIAN. His unparall[el]ed cowardice!

HEAD. Eh! cowardice! Yes, yes, truly; for he blustered much, and that is a sign of cowardice.

DIAN. His meanness!

HEAD. His devilish impudence, girl! He would have robbed me of my daughter, and fifty thousand dollars.

DIAN. Well, sir, and is your strong box opened yet?

HEAD. No, zounds, no.

DIAN. Then you have yet lost nothing?

HEAD. Nothing.

DIAN. I am glad of it. I thought he had robbed you of something better than fifty thousand dollars; I thought he had robbed you of a friend!

HEAD. Eh!

DIAN. Yes, sir. Is not he, who by base detraction, robs one of a friend, more criminal than he who rids you of a little sordid pelf?

HEAD. How now? Are you mad? 
DIAN. Mr. Ravin told you this! Mr. Ravin! and who is Mr. Ravin, that he should coin these unmanly, improbable, preposterous falsehoods? - O my father, I do not so much lament his depravity as your credulity.

HEAD. My credulity, girl? Take care of disobedience and irreverence.

DIAN. I will, I do. But I cannot restrain myself, when I hear a malignant slanderer venting his hints, his doubts, his regrets, his suspicions behind the back of his victim.

HEAD. Nor can I restrain myself, when I find a villain that should house in a jail, making free with my parlour, and my daughter, and my money.

DIAN. This villain has deluded you.

HEAD. This villain was shot in defending you.

DIAN. But I was saved by Mr. Raleigh, when Mr. Ravin could defend me no more.

HEAD. Fudge, fudge! a plan, a plot, a stratagem! A contrivance to appear heroical; one of the villain's commonest tricks.

DIAN. Just heaven! is it come to this! Sir, I have but one more word to say: Send for Mr. Raleigh, confront him with the slanderer, and let him know of what he is suspected.

HEAD. And have bloodshed between them! or, by apprizing him of our suspicions, allow him opportunity to escape! Not so, girl. Let us have but the proof, the proof, and then-

DIAN. I conjure you, father, to send for him, or write to him, or go to him.

HEAD. To satisfy you at once-I will neither go to him, nor send for him, nor write to him; but I have written to Mr. Washington Raleigh about him, and shortly he will have such a storm raised about his ears as will confound him. I have already forbidden him the house; and 'tis 
not an hour since he had the door shut in his face. Daughter, if you will avoid the eternal disgrace of having it said you loved a common swindler, now is the time to give the world the lie by receiving the addresses of a gentleman.

DIAN. of a knave, you mean, sir.What, the back-biter, Ravin? From the bottom of my soul do I loathe and despise him.

HEAD. Hark you, minx; don't talk this way. I give you to know, you shall love any body I please, and marry any body I please. What, you jade? - I will cast you off, I will build a church with my money, and leave you to pray in the street, you graceless rebel, I will. I ]

DIAN. O, my Father!

HEAD. Father me no more, unless you return to your duty. you are no more daughter of mine, unless you receive Mr. Ravin henceforth as your avowed and accepted lover. Think of it, and repent of your disobedience.

(Exit.

DIAN. As my avowed and detested enemy! He will not acquaint Mr. Raleigh of his slanderous nonsense; but I will, and that presently. I have heard him say his only acquaintance in town was my cousin Roslin Oh! why did I not think of him? He could clear him. He returned to day. I will away to him, to his house - and he shall apprize Raleigh,_-or I may see Raleigh with him. They may call this step boldness; but here it is generous to be bold.

(Exit.

SCENE 3. A street with a lighted lamp. (Enter BOLT, RING FINGER, MOSSROSE, end CROSSBAR.

BOLT. We're all very good fellows, and good fellows should go the crony: therefore, doctor Ringfinger, let me introduce you to my friends. This is Mr. Mossrose, the poet, a sonnetteering quill-driver, lapdog to the ladies, and hackhorse to the newspapers. His friends say he IS an excellent writer; but in my private opinion, he 
is better at making a pen, than using it.

RING. Golly! Mr. Bolt is satirical.

MOSS. Sir, in your ear, I assure you, Mr. Bolt, though a clever fellow, has no taste in matters of poetry. Be not guided in such matters by his judgement-His taste is very morbid.

BOLT. This is Mr. Crossbar, my good friend,-and he is a dandy;-more troubled with sour stomach than sweet breath, and as much afflicted with a thin leg as a thick wit. He is both well-bred and quarrelsome, and is considered to make the worst bow, and the best apology of any man in town. He is in great favour with the ladies when his leg is well stuffed, and with the gentlemen when his pocket is well furnished: otherwise he is a great bore, for dyspepsia prevents his drinking, and ill humour stops his laughing.

CROSS. Mr. Bolt, if you mean that for an insinuation-

BOLT. No it isn't; 'tis a plain speech.

CROSS. Well if it isn't an insinuation, I say nothing about it; though I must confess you speak freely.-

BOLT. Pshaw! I did but go over your characters, to save the doctor the trouble of finding them out; and you are both welcome to do the same for me.

MOSS. Are we? Then Mr. Bolt is one, who, being too stupid to learn, prides himself on being an ignoramus.

CROSS. He has a big leg, but it is devilish crooked, and fit for nothing but kicking.

MOSS. And having no genius of his own, he always decries it in others.

CROSS. And because he is naturally very impertinent, he has learned to box, in order that he may beat those who resent his insults.

MOSS. He is studying the laws, - 
CROSS. And always breaking them.

MOSS. He is drunk three times a week.

CROSS. And is only sober when the taverns won't trust and his friends won't treat him.

MOSS. And when they do, out of his gratitude, he bilks the tavern and beats his friends.-Every word gospel.

BOLT. Well, now our characters are drawn, let's draw aside, and speak to the ladies as they pass.

MOSS. It is rude, and also unlawful.

BOLT. There's no law in the land against speaking, unless it be in slander, menace, blasphemy, or contempt of court; of all which the last has the heaviest punishment.

MOSS. Not above slander.

BOLT. Slander should be excepted; for slanderers are punished, not because the crime is more heinous than the others, but because there is more folly in it; For if a man will spend but twenty four hours in making himself master of Actionable words, he can say what mischief he likes, and that safely.-I will give you an example how to accost ladies in the street. If they walk alone after nightfall, they are fair game. Stand aside: here comes one. (Enter an ugly old woman.) Good evening, Miss Rosa Angelina - a fine evening.

O.WOM. Did you speak to me, sir? (She turns her face to him in the light of the lamp.)

BOLT. No, mother Skin-and-bones. (Exit old woman.

OMNES. Ha, ha, ha!

BOLT. We must expect a horrification sometimes: but here comes another, of a younger and modester carriage, for she bends her head and walks fast. (Enter a negress.) Bon soir, ma belle enfant. Shall I have the pleasure of giving you my arm? 
NEG. I am much obliged, sir. (Shows her face in the lamplight.)

BOLT. Out! you imp of pitch and charcoal!

(Exit negress.

OMNES. Ha, ha, ha!

BOLT. Gentlemen, you may laugh; but it is always well, when the black skin admonishes us of a black heart, which is not always to be detected under a white one. The third, however, is said to be the charm, and here comes one that has a very charming appearance.

(Enter DIANA.

MOSS. Don't speak to her; she looks like a lady.

BOLT. Nevertheless—My dear madam, I thought you would never have come. A delightful, pleasant evening.

DIAN. Sir, sir!

BOLT. Yes, very pleasant indeed; and if you will take my arm, we will soon find a better place to enjoy it in; $r$ for upon honour you have a ravishing face, and I-

DIAN. Sir, you insult me.

BOLT. That's because I haven't kissed you. 'Tis very insulting to a lady to compliment her lips, and not kiss them. So, my dear-

DIAN. Ruffian!

BOLT. That's right; I like a little resistance: it makes one look innocent.

(Enter TOM TAFFRAIL.

TOM. Avast there, my hearty, or I shall draw my forepaw athwart your hawse. Cast off your fast, and let that 'ere tender go.

(Exit DIANA.

BOLT. Now, fellow, I will break your bones.

TOM. Ready, lubber! Stand by for a bend, my hearts; and 
now, my cock-chicken, for a rough gaff or a smooth heel. (They scuffle; the others menace TOM; he knocks BOLT down, and chases CROSSBAR out.

MOSS. He's killed.

RING. Desperately mauled: the fellow's fist ran over his face like a carriage and six horses over a turnpike; I saw the fire flash at every knock.-He is in a dead swoon, pulse thick, breathing stertorous, and nose bloody;- - believe his neck is broken. Go, call a hack, Mr. Mossrose: we must take him to a tavern, where I'll bleed him; (Exit MOSS ROS E,) but first I might bleed him here, for a well filled pocket is not to be found every day in the year; and yet I won't, for Ben says it is a low vice,--No, I won't. (Picks his pocket.) How natural it comes! How natural it is to empty this pocket book, and cast it into the gutter! how natural to separate this loose change, throwing the copper upon the pavement, and the silver into my own pocket! how natural to tear open this fob in the scuffle, and put the patent lever into my own, for fear it should be trodden on. Beelzebub, thy name is Temptation! and Frailty, thy name is Ringfinger! Would that I knew a dozen such fools: I would have them in a broil or a debauch once a week, and then when they were drunk or beaten dumb, temptation would persuade, and I, frail that I am! I would pick their pockets. - Mr. Bolt, how d'ye do? Silent as a tombstone, or a dead woman. Well, silence becomes a fool, and gravity a philosopher; to which may be added, picking pockets becomes myself.

(Enter MOSS ROSE and a hack-driver.

MOSS. How is he now.

RING. Much better; though he will feel the worse for it, when he comes to.-Gingerly, Mr. Whip; handle him as you would handle so much glass, for if he falls, he breaks; and indeed I am afraid he will find his fall has already broke him.

(Exeunt.

SCENE 4. Another street. (Enter RALEIGH, JR.

RAL. By heavens, 'tis inexplicable! Denied admission, 
told saucily by the rascal at the door, that his master $\mathrm{g}$ was at home, but did not choose to see me! and desired $\mathrm{g}$ me not to call again! There must be some damnable delusion or witchcraft prevailing in this city, and especially in Headstrong's house. I suppose my honest friend, the Yankee, is at the bottom of all this. Curse him, if I find him-(Enter DIANA.) Am I awake? Diana! alone, and at night!

DIAN. Oh, Mr. Raleigh, this is lucky! I am scared half out of my wits-If you have your bamboo with you, I beseech you, beat the first man you meet in the streets; and then beat the second, and then the third -and then-

RAL. This is very strange, madam!

DIAN. Oh, sir, they all deserve it. This a polite, this a well bred, this a civil city! Odd's my life! I never saw such impudent villains! I have travelled twenty yards, met twenty men in the street, and of these, nineteen were impertinent. That's breeding for you!

RAL.JR. . And why have you exposed yourself to impertinence, madam, by walking unguarded through the streets?

DIAN. Because I didn't know guards were necessary in a time of peace, to protect a woman. But you are very ungrateful to ask such a sulky question: I came entirely on your account.

RAL.JR. On my account!

DIAN. Yes. I had no way of seeing you since my father has denied you the house; and I thought I might hear of you at my cousin Roslin's. So, now I have found you, promise me you won't fight, and I will tell you why my father has been rude.

RAL.JR. . I can make no promise, Diana, that, as a gentleman, I may afterwards repent.

DIAN. But you must though. Sir, you have been slandered; and my father is made to believe you are that bad man, that Mr. Garket, whose name so confounded you when you were introduced to Mr. Ravin. 
RAL.JR. 'Sdeath! your father is an old-

DIAN. Hush! You mean Mr. Ravin; 'twas he that possessed my father.

RAL.JR. Humph! If I don't-

DIAN. Canehim:-yes, you may do that; you may beat him as much as you will; but don't fight him with pistols, or swords, or daggers; - he might kill you.

RAL.JR. Ha, ha, ha! but he might take the cane out of my hand, and beat me!

DIAN. O. then you can get some stout fellow, for three or four dollars, to beat him for you; and bid him lay on well. I do so hate the manse if I was strong enough I would beat him myself.

RAL.JR. Pr'ythee, don't talk that way; it frightens matrimony out of my mind. Come, I must take you home.

DIAN. And I hope you will beat some of these impudent wretches along the way. But you must not enter.

RAL.JR. I will not. I have some doubts whether I shall ever enter your father's doors again; and certainly should not, but for his Diana's sake.

DIAN. Come to morrow, and bring my cousin Roslin with you. He knows you, and he can convince my father of the folly of his suspicions.

RAL.JR. I will not do my pride such insult. Let him seek me, and do me right; I ask it not of him; nor will I trouble myself about explanation, where I have not injured.

DIAN. That's a magnanimous goose! But come along, and make ready to beat somebody.

RAL.JR. Beat somebody! for being good-natured<?> to you? Isn't this called the City of Brotherly Love?

DIAN. Yes. 
RAL.JR. Then I won't beat the impertinent knaves; for these were only so many specimens of brotherly love!

(Exeunt.

SCENE 5. A room in MRS. GALL'S house. (Enter MRS. GALL and RINGFINGER.

RING. Come now old lady; this is contrary to my notion of things: if she a'an't your daughter, whose daughter is she?

GALL. Your brother would kill me.

RING. Never fear. Whenever any body is disposed to kill you, cry Penitentiery! and he's off in a hurry. It is your interest to tell. If she be a rich man's daughter, why then, with your help, l'll marry her, and share her fortune with you.

GALL. I should like that very well; but your brother-

RING. My brother, by reason of more mischief and good looks than I possess, is already, to my certain knowledge master of one lawful wife, and for aught I know, may have a dozen more. I am a bachelor.

GALL. But then the girl herself,--does she like you?

RING. I reckon not. I wanted to kiss her t'other day; but she cried and promised to tell Benjamin. So I conclude she don't fancy much after me:-But that's nothing.

GALL. Then I can't tell you her name. If she don't like you, you'll never get her; and I believe Benjamin wouldn't consent to it. yet there is one way by which you may obtain her.

RING. Mention it.

GALL. Kill your brother.

RING. I believe, old woman, you are mad. I have resolved never to kill any body in a state where they build Penitentiaries; and even if it only ended in hanging, I 
shouldn't kill my brother, not I.

GALL. Then you can never have Emma. I tell you, if you put him out of the way, you shall make your fortune. He stands in your way, he stands in mine. I stole that girl to obtain my own ends, and he thwarts me. I have bred her from childhood, I have wasted money on her, I have schooled her like a lady; because I had an end in it, though I hated her. I would have made her a touchstone, to bring me gold, and a miserable tool to bring me revenge; and when her charms had become valueless, would have sold her with the secret, which would make her husband rich: and yet he comes athwart me, and orders me to keep her as well as myself at his disposal; and I am forced to obey him.

RING. And how the devil has he such power over you? not from love?

GALL. From love! No, I hate him, and would do him a mischief,- - but that I fear him. He has my secret, which, if he told it, would condemn me to prison or hanging for aught I know. I stole the girl for revenge, and he plucks revenge out of my hands.

RING. . Mother Gall, you appear to have a blood-thirsty disposition, a spice of the devil in you!

GALL. Have I not reason? That girl's father made me the dupe of his villa[i]ny; (I was young then, and no haggard as I am now;) made me promises, and laughed me to scorn when I reminded him of them, for I was poor and lowly; and instead of making me the mother, made me the slave of his brats.

RING. Why didn't you sue him for breach of promise?

GALL . Because I had a spice of the devil in me, as you say; and I coveted his blood more than his money. His blood? -no, not that, but something that would hurt him more. I swore to be revenged, and revenged in a manner that would satisfy me best, and injure him most. I slaved patiently in his house among his negroes; I watched, endured all patiently, patiently! till his wife bore him a daughter, and then- 
RING. Go on: this sounds like a gallow's confession.

GALL . And then I stole her away, taking care to possess myself of such articles as would serve to prove her birth hereafter, her mother's picture and necklace; and pricked a mark on her arm, which her father has seen, and will be obliged to acknowledge.

RING. And so you revenged yourself upon the naughty man by taking his daughter from him?

GALL. I meant to have revenged myself by restoring her to him.

RING. A very Christian-like resolution.

GALL. But I would have restored her to him as vile and as infamous, - ay, ten times more so than he made me. I should have sent him a harlot for his daughter.

RING. Zounds! that was a plot for a woman! No man would have thought of such a thing.

GALL. And your brother, by recognizing me, has taken her into his own hands. I dare not scold her, but he threatens me. Therefore I hate him, and if you will kill him, you shall make your fortune. Or if you have the spirit, you can aid my vengeance by-Do you understand?she is alone.

RING. you are a damnable old devil, mother Gall, and I suppose you are expounding concerning a rape. But I tell you again, I shall never do a fault that would send me for life to the Penitentiary; and besides, brother Ben has as much of the devil in him as you; and such a freedom with his own game might lead to a fracas.

GALL. I wish your brother were rotting at the bottom of the Delaware, and you, for a prating coward, be side him! I will not bear his tyranny any longer. If he has a secret of mine, I have one of his; and I don't know why I shouldn't as well threaten him, as he me. I will be his slave no longer. (Enter RAVIN, drunk.

RING. Speak out then. I long to see any one that can 
talk big to Ben, for dammee if I ever could.

RAV. Mother Sanctity, are you drunk?

GALL. Lord bless you, Mr. Garket!

RAV. Dame Kidnapper, if you call me Garket again, I'll report you to the mayor of this goodly city as a

nuisance,- - a nuisance, old beldam, a nuisance: They allow no nuisances here, except negro class-meetings, dogs, and church-bells. And so get you to bed, or l'll have a constable on you in the cutting of a pack, or the emptying of a bottle.

RING. Speak out, old lady.-Why where's your spunk? (Exit GALL.

RAV. Well Jack, what's the news?

RING. That old hag has been telling me all about Emma.

RAV. She lies. she is afraid to tell, without indeed she were drunk; for drunken people can keep no secrets.

RING. Then I hope, Ben, to hear yours directly.

RAV. You lie; I a'n't drunk; I am only terribly good humoured. I met the adversary, and scared him off. He making love to Diana too! He may have her, after I've done with her.-But where's Emma?

RING. Emma who? Come Ben, she has told me everything but her real name.

RAV. I can't tell you that, Jack; but I'll tell you where you may find it.

RING. Where?

RAV. In the family bible. So you see, I am very communicative.

RING. Humph. Let s go to work. you must fill up some notes, or practise some of these signatures.

RAV. I won't; I'd rather make love. 
RING. Eat a pickled cucumber, and get sober.

(Exit RINGFINGER.

RAV. (Sitting.) Love! omnipotent devil! how devilish omnipotent art thou! especially over a bottle, or after one. Your lover of a woman is always your friend of a bottle; except it be empty, and then love is but an empty passion: I love Diana exceedingly, and so I do Emma, and so I do my wife. But my wife is like bad wine and has turned sour on my stomach; Diana is like malt liquor, damned stupifying, and apt to Jay grow stale; whereas Emma is like your true cogniac, t" the very smell of which sets one's heart and head at loggerheads. (Enter EMMA.

EM. Miserable that I am! Oh, that a mother should thus tyrannize over her child.

RAV. Cogniac is a great mover of spirits, so is Emma; cogniac is a great provocative of love, so is Emma: I will now see whether Emma be as easily gotten as cogniac, for cogniac makes me monstrous loving. Basta, damosella! hast thou been at the flagon too that thine eyes are thus running over?

EM. Sir, I was, I was-

RAV. Thou wert coming to me, my pomegranate blossom, to wrap thy dainty little fingers round my neck, and discourse most agreeably of the falsehood of lovers. Come sit thee down, and prattle lovingly, for thou and I shall be married.

EM. You are merry, sir. I must wish you a good night.

RAV. I tell thee, thou apple of my two eyes, we shall be married. Odds boddikins! sweetheart, why do you cry?

EM. Sir, my mother has occasion for me.

RAV. And so have I, thou water-eyed Niobe. Come and kiss me.

EM. He is certainly intoxicated.-Good night, sir 
RAV. Pr'ythee sit down and kiss me; for I must say sweet things to thee.-Fy on thee! thou hast no Demogorgon making love to thee.

EM. My mother demands my, presence, sir.

RAV. Thy mother be damned! Now thou hast not love enough for the old hag, to be vexed at me, for all of thy startings, thy dignified startings. Thou hatest her horribly now?

EM. Sir, if you will let me pass.

RAV. Come, I will kiss thee numerically, by arithmetic: I will skip from addition to the Rule of Three till we be in full Practice; thence from Simple to Double Position; and thence to Promiscuous-

EM. Release me, sir, or I will call my mother.

RAV. Thy mother be damned, as I said before. For what is thy mother, but a devil sent from below into earthly exile, and called Kidnapper by courtesy. Swear to me that thou dost mortally hate thy mother.

EM. Unhand me, Mr. Ravin.

RAV. Come, wench, thou hast the most admirable eyes; and then for thy lips, I will taste them.

EM. Ruffian! are you a man, a gentleman, Can thus oppress the weak and innocent? Away! go blush for your unmanliness: Let me go weep.

RAV. Yet for all this will I kiss thee; and then, thou excellent little obstinacy-

EM. Help! mother, mother! help!

RAV. Pish! she can't hear; or if she does, she knows better than to break in upon one's courtship.

EM. Be she more cruel and unnatural Than crocodiles with their young, she will not suffer A slave, a ruffian to oppress her child. 
RAV. Child! ha, ha, ha! Thou art a wonderful child, for thou hast more than one mother; and though a child with two parents is no such uncommon sight, yet a child with two mothers is rather an oddity.

EM. Two mothers! what mean you?

RAV. Thou wilt fall into a fit, if thou starest thy

little eyes so out of their sockets, with thy mouth open

EM. Two mothers! two mothers!

RAV. Nay, you have but one natural mother to be sure.

EM. O sir, you are more cruel than before, Thus to make sport out of my misery, And raising, for your mirth, a wild strange hope, Which, for your mirth again, you mock from me.

RAV. Thou art the sweetest mouse! Kiss me, and tell me you hate this old kidnapper.

EM. This old kidnapper! Trifle not with me, sir. She is my mother, and I cannot hate my mother.

RAV. She hates you.

EM. You wrong her, sir. It has been my misfortune Never to meet a cherishing love in her:

But yet she does not hate me.

RAV. Most orthodoxly; and you would give one of your eyes to learn you would be no sinner in paying her back in her own coin.

EM. Sir!

RAV. Will you kiss me pleasantly, yea amorously, if I tell you something of your birth and your mother?

EM. Something of my birth and my mother! Is she not-? Speak! I know that mystery As well as infamy was on my birth.

RAV. If I should tell thee, Mother Gall was not thy 
mother?

EM. I would bless you,

Pray for you, serve you like a slave, although

I knew you mocked me; I would-O heaven forgive me!

This is unnatural!

RAV. Kiss me your thanks, and have it so; for she is not thy mother.

EM. Not my mother!

Mock me not, lest I curse you: do not make me

Grow mad with disappointment; be it rather

Mad with delusion: say it once again,

Say Not my mother; swear it, Not my mother!

RAV. Be loving then, for, by the lord, she is no more your mother than I am; and that no one in his sober senses-

EM. Heaven, I thank thee!

Be misery my lot, not infamy!

RAV. Now for rewarding the good news.

EM. Tell me who is my mother?

RAV. Thy mother be damned! Come, let us kiss like two doves of a summer's day.

EM. Who was my mother?

O take me to her; let me leave this house;

Take me to her: If she be poor and needy,

I am young and strong: O take me to my mother,-

If she resemble not this wretched woman.

I'll leave this house.

RAV. Upon my honour, you sha'n't; for here you shall stay, and be my most excellent-

EM. Off, slave!

RAV. If thou wert more ungrateful than the devil, and more angry than his enemies, I'll tell thee I am thy master, and love thee.-You have been paid for, and shall not prove a bad bargain. Understand me: you are 
handsome, and I am drunk, drunk with love and brandy together; and mixtures are always more powerful than plain stimulants. I am particularly loving tonight, and tonight I mean thou shalt be so too. So no qualms of conscience, nor nonsensical strugglings-

EM. Brute! I defy thee! For thy strange confession, Which drunkenness, not kindness, forced from thee, I thank thee: But I will not be thy slave.

Follow me not-I shall go hence.

(Exit.

RAV. I am mad-drunk; but ye shall not escape me. (Exit, pursuing her.

SCENE 6. She street before MRS. GALL'S house.

(Enter ROSLIN.

ROS. I have been told, that oft of nights this Ravin,

Muffled and cloaked up to the eyes, is seen

Stealing through this deserted quarter of the city;

Nay, in this house is sometimes seen to creep

On his illicit errands.- - Here he saw her-

(Who else but her, here in her mother's house? )

Blighted, and sadly gazing on the sun, Like a fall'n angel on the glorious orb

From which her sins had cast her: and there is In a fall'n woman the sad and fading semblance

Of a lost seraph, one on whom our tears

Much oftener should be shed than our sharp sarcasms.

Could she thus fall? she, whose sweet lips seemed ever

To breathe a heart out in their melodies;-

A heart that was so delicate and gentle, Methought a rude word would have broken it; And so forlorn, it leapt at friendly voices In a submissive gratitude and joy. Could she fall?-Hist! by heavens, it was a shriek! A woman's scream! Are there no watchmen here?Voices and struggling! 
EMMA (Within.) Spare me, sir, for pity.

ROS. With your leave, bolt! if I have weight enough.

with

(Bursts the door; enter EMMA, struggling

RAVIN.

EM. O save me! Take me to my mother.

ROS. (Striking RAVIN back.) Villain! stand back, or I will tear your heart out!—Courage, poor unfortunate. She swoons!

RAV. Dog! give her back.

ROS. Thou worse than dog! thou beast, Without a name to express thy lust or fury! I know ye!

RAV. Ye shall. Be wise, and begone.

ROS. Slave! take ye that; (gives his card) and if ye have a grain

Of manhood in ye, ask of me tomorrow

The chastisement brutality deserves.

Nay, follow not: If you advance a step,

'Tis but a call will bring the watch upon you,

With all the infamy you've won to night.

(Exit, bearing EMMA.

RAV. Fiends! furies! devils!

This is it to be drunk! Up, ye old hag!

Ye kidnapper! ye gall-bag! up, I say.

(Enter GALL, with a light. He reads the card.)

Roslin! ha, ha! This is it to be drunk!

Drunk, drunk and mad! Lost, ruined, blown, and ruined

Game gone,_Diana, Emma, lost! both lost!-

This cursed Roslin!-—out, ye hag, and get her;

Fetch her again, or I will wring your neck;

Fetch her: begone. (Exit GALL, terrified.) But you shall rue it well,

Meddlesome boy! if there's in steel or lead

A medicine will help me to revenge!

(Exit. 
ACT THREE.

SCENE 1. A room in ROSLIN'S house. (Enter ROSLIN and NATHAN.

ROS. Has the-'Sdeath! am I grown shame-faced before my own boy?-Boy, have there been any calls to day?

NATH. There came a tailor with a bill a yard long; but seeing you were melancholy, I told him his present suit didn't fit: and so he took a back-stitch, and measured the street towards his cabbage garden. Then came a cobbler, a son of wax, with a bill like a Canada petition, having but one end, which was the beginning; his items were, like mocasin leathers, put on without soul, and no man while looking over 'em, could tell where was the last of 'em. As for him-.

ROS. Has she shown herself this morning?

NATH. She!

ROS. She, simpleton? Your wits were not used to be so dull.

NATH. Indeed they must be stupid now; for I have been worrying my brains an hour, and never a laugh for reward: and one can't be witty long, unless one can raise a roar. Now sir-Odds my life! I think he has been guzzling porter, for he is as stupid as a brewer.

ROS. If it has come to this, the conclusion is but a throat-cutting or a hanging in one's garters, both of them sovereign remedies for ill advised love. Love! foolery and madness! What, a mistress! a-a-perhaps a-O heaven! that such a face of beauty and innocence should be the mark of a soul befouled with passion and pollution! Curse her hypocritical looks! Why did I bring her here?

NATH. Now is he seized with a mad fit, for he is gritting his teeth like an alligator or a ground hog.

ROS. She can swoon, she faints admirably; that is easily 
learned: and she can weep,- - so naturally as to give one the heartache; but I have heard how that may be learned too: 'Tis but a stretching of one's eyeballs, with a little forcing of passion; and out they come, the watery hypocrites! Death! what care I? Let me be but rid of her, and put her in some honest situation, and then forget her.-Well, Nathan!

NATH. Sir, I was going to tell you of a comical dream I had last night; it beat Nick Bottom's hollow. Methought I had fallen in love with an oyster, an overgrown oyster; and in this dream-

ROS. A dream! And I have had mine too. This girl! methought she had wings, and was an angel; but her wings were broken, and she wept over them-

NATH. And this oyster-

ROS. One that was driven from paradise. not for a sin, but because-

NATH. And this oyster, this overgrown oyster-

ROS. Ha! this what?

NATH. This loving oyster that I dreamt of.

ROS. Ha, ha, ha! have you been dreaming of oysters?

NATH. Yes, sir; I was in love with an oyster: but that part of the vision I do not wonder at, because, like ancient Pistol, the world is mine oyster, and the world I love very well: but the strangeness of it was, that the oyster changed to-to-that-that-

ROS. To what, sir? Why do you pause?

NATH. Nay, if I had known her name, you should have heard it afore this:- to that pretty damsel that you brought here last night.

ROS. Let me see your discretion shown, in not speaking of this pretty damsel to any living soul but myself; nor even to me until I invite you. 
NATH. Umph! Now comes on the fit again; and no more talk of my oyster.

(Enter RALEIGH, JR.

RAL.JR. Morrow, morrow.

NATH. Gently, sir. If you have any thing witty to say, pray call on some of the neighbors. Wit has a poor purchase here to day.

RAL.JR. Trust me, young Ganymede, I will neither afflict thee nor thy master with anything more current than dulness. So let thy wisdom take itself away, while I convince him there are more serious asses in the world than he wots of. (Exit NATHAN.) When you have finished your meditations, school-mate, I shall be at your service. Humph! the man has met with a misfortune, and has suddenly grown deaf, dumb, and blind. Such a one would make an excellent lover; too blind to find faults, too deaf to hear of them, and too dumb to jeopard his soul with excessive lying, which is the chief excellence of a lover. Taste, touch and smell for his money; and all he could look for in a woman would be a sweet breath, a smooth skin, and a ; I delicate lip. Surely the man is in love, and-Zounds! if that isn't a petticoat, there's no dimity in the land!

ROS. Stay!

RAL.JR. There now, she is vanished! Thunder and lightning! what ails you, man? Are you sick, or in love?

ROS. Neither. I was trying to remember when it was the last honest woman appeared in this world.

RAL.JR. Was that dishonesty I caught a glance of just now?

ROS. If it was woman. But pass that.-How go matters with you and my cousin?

RAL.JR. Well, and badly. Well, for I have had all reasonable encouragement; and badly, for I have been turned out of doors.

ROS. Do you call that reasonable encouragement? 
RAL.JR. No-but, Roslin, look very attentively at me, and tell me if I look much like a rascal ?

ROS. I observe no strong resemblance.

RAL.JR. A coward?

ROS. More like a cut-throat.

RAL.JR. But, by Jupiter, I am both rascal and coward; If and I should have taken no offense if every ambling I55; booby in Chestnut Street had pulled my nose as I $g$ passed along: for I have been grievously insulted, and have borne all as tamely as a starved dog.

ROS. Impossible!

RAL.JR. You have an uncle called Headstrong, an old man.

ROS. Yes.

RAL.JR. And an impertinent old ass.

ROS. At your service.

RAL.JR. Do I look like a felon? a swindler? a bankrobber?

ROS. Are you serious?

RAL.JR. I have been taken by your honest old uncle, for Benjamin Garket, Esquire, my cousin the knave; and on the strength of this fancy, I have been denied his house.

ROS. I am lost in amazement! What could have put this ridiculous folly into his head?

RAL.JR. Robert Ravin, Esquire, of New Hampshire.

ROS. Humph!

RAL.JR. It is Diana's particular desire that I sha'n't fight him; and therefore I desire your advice as to the eligibility of pistolling or horsewhipping him; which 
last Diana fancies most; and I am inclined to her opinion.

ROS. He is beneath your notice.

RAL.JR. Why then the horsewhip.

ROS. You are forestalled. To my certain knowledge, he is now under obligation to fight another man; and your resentment must be deferred until after the adjustment of this affair.

RAL.JR. Is he so quarrelsome? Who is the man that fights him?

ROS. You shall hear presently-Well, sir, what is the matter now?

(Enter NATHAN.

NATH. A gentleman with a black-eye, to speak with you. He calls himself Bolt, and looks as savage as a singed cat: I was going to bolt him out, but he bolted right in.

ROS. Show him up.

RAL.JR. And who is Mr. Bolt?

(Exit NATHAN.

ROS. A representative of a Philadelphia buck; one that with the opportunities of becoming a gentleman, amends his gentility by the addition of certain accomplishments peculiar to the vulgar: that is, he has been half educated at college and half bred at home; is seen sometimes in a lawyer's office with the last new Jest Book in one hand, and the last old Blackstone in the other; more frequently in the tavern with a terra-pin under his nose, and a wine bottle at his elbow: he fiddles a little and boxes to admiration; wears a costly coat; keeps a mistress, and sometimes a dog; above all, he can brag of having shot one grouse on the Jersey colings, and one man on the Delaware lines.

RAL.JR. If you have business with him, I will take my leave 
ROS. By no means. I shall need your assistance. Here he comes. (Enter BOLT.) Your servant, Mr. Bolt. This is my friend, Mr. Raleigh.

BOLT. Your servant, sir; and yours. I had some private communications-

ROS. Mr. Raleigh is my friend, sir; and if I understand the object of your business rightly, any communications to me may be properly made in his presence.

BOLT. Then with your leave, sir,-From Mr. Ravin. (Delivers a challenge.

ROS. As I expected.

RAL. How, Roslin! Are you the man that appears in this business?

ROS. The same. I accept the invitation, sir; and refer you to Mr. Raleigh for arrangements.

RAL.JR. Hum - this is a devilish strange piece of business! That was a challenge, sir, if I mistake not?

BOLT. The very same, sir; and as it appears we are appointed mareschals do camp, I must beg to be in-formed when and where we shall meet to arrange matters?

RAL.JR. In an hour's time, sir, I will attend you at the United States'.

BOLT. I will be there, sir. Gentlemen, your servant. (Exit.

ROS. Yours, sir.

RAL.JR. If you happen to be killed, Roslin, it may be of some satisfaction to my conscience and some service to your memory, to know what you are to fight about.

ROS. A woman.

RAL.JR. Hum—very satisfactory. 
ROS. You may recollect having seen and described a handsome girl to me as Ravin's-

RAL.JR. 'Sdeath! have you been poaching?

ROS. I happened to rescue this unfortunate creature from his drunken brutality, and put her out of the reach of his violence. This is the cause of the quarrel.

RAL.JR. What have you done with her?

ROS. She is in this house.-Do not start: you have been deceived in her character.

RAL.JR. I should have thought any asylum had been preferable to your mother's house.

ROS. Do not mistake her. she is innocent. She is that strangely unhappy girl I wrote you about, as having seen in-

RAL.JR. What, the bawd's daughter! and innocent! Lord, lord! worse and worse! Why the vengeance did you bring her here?

ROS. What else could I do with her? What decent lodgings would receive a young woman at night with no other recommendation than that of a young man? Do not suppose if I had thought her base, I should have brought her here.

RAL.JR. Thought her fiddlesticks! Zounds! must you peril life or limb, go out to mortal combat, in upholding the reputation of a bawd's daughter? and must you eternally disgrace your own by sheltering her under your mother's roof?

ROS. You do her injustice.

RAL.JR. And another man's bona-roba too! If you had told me this before, I could have prevented this rencontre.

ROS. If you are dissatisfied with your part in it, I can release you from your engagement, and look elsewhere for assistance. 
RAL.JR. You shall not need to do that, sir. I can lament nothing in this affair more than your causeless displeasure.

ROS. Forgive me. I have a weight on my mind that makes me neglectful of what I say.

RAL.JR. Farewell then. Come to my lodgings this evening, and I will read you the rules of combat. Till then, keep the unhappy cause of this unhappy affray out of your sight.

(Exit.

ROS. All men grow wise and prudent, while I am settling into folly and infatuation. I have seen the day that I could give Raleigh the counsel he has been giving me. He was used to be thoughtless and hotbrained, but not so obstinately bent on ruin as myself. - Yet she has not the look of an abandoned one; no hypocrite could assume her face or voice, her simplicity, dignity, or gratefulness. But her mother!-She comes-

(Enter EMMA.

EM. Sir, I have been very anxiously awaiting an opportunity to thank you again and again for your generosity in protecting the honour of a helpless and distressed girl.

ROS. I did not think, when I saw you last in my Uncle's house, to have ever found you in need of such protection. I should not have supposed you needed it in your mother's house.

EM. My mother's! Oh sir, you have been much deceived. That wicked woman is not my mother.

ROS. Not your mother!

EM. No, sir; and if I may tax your kindness once more, send to her house, and beseech of her who are my parents?

ROS. Heavens! do you not know them?

EM. If I did,- -if I had, sir, think you I would have remained with her, my hard oppressor, to meet her daily 
cruelty and insults?

ROS. She not your mother! Be sure you are not deceived.

EM. Never. Nature belied her pretensions, for I hated her. Oh, I knew this would please you, for you were used to take an interest in my welfare.

ROS. Please me! Indeed it does. But why should she- how dare she call herself your parent?

EM. I know not. From my earliest years I was brought up at school, where she came privately twice a year to ask about me, and provide for me. Those were happy times for I had friends then. But when some one whispered scornful tales about her, they all shunned me, and forbade me their houses. You know that. Then she took me away, and kept me close at home, where, as I learnt by his own boasts, she sold me to that villain, from whose brutality your kindness saved me, - that man who before had never been rude to me, till in his drunkenness he forgot himself, boldly avowed that he had bought me, bought me! of that bad woman; and then to gain my gratitude, said she was not my mother! Then I fled from them; he followed me; and you, you saved me from him.

ROS. And therein have conferred more happiness on myself than I know how to express. - oh heaven! There is an innocent soul speaks in her every word! no vice could look thus.-You have been unhappy: There is a mystery about your origin, which I will use my best means to unravel; and I will associate my best friend, my mother, in the search. Meanwhile, be at rest; consider yourself mistress of this house. My mother will be here at farthest in a few days, and will then give you protection and friendship. Till then, I myself will feel honoured in defending you from the insults of your friends and the machinations of your enemies.

(Exeunt.

SCENE 2. A room in MRS. GALL'S house.

(Enter GALL and RINGFINGER. 
RING. Now, old lady,what d'ye think of matters? Didn't you dream all last night of penitentiaries? or was you fancying all the while that Benwas cutting your throat?

GALL. Vex me not, rogue; I am ruined.

RING. And what's that to Ben? He is ruined himself, he says. Gadswogs! to take on so after a scornful little wench, that's too cunning for deviltry, though a devil, mother Gall, was her teacher! A little piece of bread and butter! a gingerbread! I never thought him such a fool. I could pick him a dozen as handsome, and ten times more loving out of any state prison.

GALL. He threatens me too; and he knows 'twas all his own fault. He told her, I was not her mother; that's my fault too, I suppose; and 'twas my fault that he was so beastly drunk.

RING. . Old lady, that's another weakness of Benjamin's; he will be sewed up at times. Now, for all of his wit, I have more wisdom: He that would be a successful rascal, should meddle neither with women nor strong drink, for they sooner or later, one or the other, betray him to the gallows or the penitentiary.-Who's that? t(Enter RAVIN.

RAV. Well, beldam, have you got her yet?

RING. 'Swags! don't scare the old fool. You'll have her in a fit, if you look so wickedly on her. you know she hasn't got her; and as it isn't likely that you will ever see her again, I'll advise you think no more about her, but attend a little more to the domestics; the manufactory suffers.

RAV. If she does not put her in my power again, I will have her hanged; and you, if you will not lose my assistance and countenance forever, you must aid her.

RING. As for your assistance, I could do pretty well without it; and as for your countenance, if it is no sweeter than at present, I would rather be smiled on by a crab-apple. But as I am naturally disposed to kindness, and a moderate degree of mischief, so there is be nothing penitentiarical in it, have at you with all 
my heart.

RAV. Roslin will be from home this evening; all the servants are in the country with his mother, except a little knave of a boy, who is said to be desperate cunning.

RING. Then it's no great matter after all.

RAV. Get her for me, and you will both be the better for it as long as you live. Be prudent, and successful.

(Exeunt.

SCENE 3. She street before ROSLIN'S door. (Enter from the house, ROSLIN and NATHAN.

NATH. And so I am to be housekeeper? I think any old woman would do better. And to keep watch over the pretty young lady? I think any old woman would do that better too.

ROS. You shall have an old woman to take the labour off your hands tomorrow, - tonight, if one can be obtained. Admit no one till I return. (Exit.

NATH. I suppose he is gone to see if he can find some other pretty damsel to bring home with him; he seems fond of them-so am I; and for all of his grum talk about oysters, and his oyster-like face, I will walk up stairs, and see whether this handsome stranger be fond of laughing or not (Exit, and disguised.

(Enter immediately GALL, and RINGFINGER

RING. Halt, you old fool. you are in the public streets; and Wisdom says, Be wise in the streets, if you are a fool in your chamber.-If there be any one stirring, be as quiet as a mouse; but when everything else is as quiet as a mouse, be you stirring. The coast is clear: ring.

GALL. Stand aside, and be ready. Gag him with your handkerchief. 
RING. Be sure you ask whether Roslin be at home: It would be but a scurvy job to walk into the parlour, and find him eating his supper.

GALL. I warrant you. Be ready. (Re-enter NATHAN.) Is Mr. Roslin at home?

NATH. No, old lady.

GALL. I want to see him on business of importance. When will he return?

NATH. Sometime betwixt this and doomsday. Call tomorrow. Night's no time for an old woman to call on a young man: 'twill spoil her character.

RING. By your leave, monkey, business must be settled tonight.

NATH. Let go of me, you ugly raggamuffin. Help! spur-

RING. Push in, old damsel. We must lock up this paroquet. It goes prosperously. (Exeunt.

(Enter TOM TAFFRAIL.

TOM. Shiver my timbers! but this here town is as dull as a watch under moorings. And I never sail into a dull harbour, but I think of a dull song, which is about as good for a serenade as any that these caterwauling dandies sing under their sweethearts' windows.

(Sings.)

Oh Kitty Kid, Hilloa ho!

Poor soul, she's dead, Hilloa ho!

Have ever ye heern the tale or no?

If not, give ear, hilloa ho!

Sweet Kitty Kid, she was beloved By cruel Bobby Bullet,

Who one day pulled his jackknife out, And stuck it in her gullet.

And then he took her body up, And hove her in the river, 
The nasty mud to be her bed, The noisy wave her kiver.

Poor Kitty Kid, Etc.

One night as he sat in the chains, The waves they made a clatter,

A grim white ghost raised up her head, And walked upon the water.

Says she, I once was Kitty Kid, Now Kitty Kid's ghost am I;

I loved you once, you cruel man, But now l'll drown you, dammee.

Poor Kitty Kid, Etc.

Have mercy, Kitty Kid, said he, For your death I am sorry.

You killed me, wretch! said Kitty Kid, When I implored to marry.

And you shall marry me yet, said she; To marry is your doom, man:

The salt sea wave shall be your bed, The whale shall be your groomsman.

Poor Kitty Kid, Etc.

Hold fast, my merry mates all, said he; Heave ahead, you fool! said Kitty.

She means to murder me, said Bob;

Said they, the more's the pity.

She twisted her fingers round his neck, And overboard him she carried, And as they sank, cried, Sailors all,

Bear witness, I am married!

Poor Kitty Kid, Etc.

NATHAN. (At a window.) Hist there!

TOM. Hilloa ho!

NATH. Catch me.

TOM. Come down then. I've no harpoon to fetch you out of a window.

NATH. Catch me in your arms, if you have any; if not, catch me on your legs, shoulders, head, or some part of 
your body, that I mayn't crush like a squash on the pavement.

TOM. Let go your fast, and take care not to poke any of your spider legs into my eyes.

NATH. Catch me-now! (He springs down, and TOM catches him in his arms.) Are you honest?

TOM. Ask the captain; he's got all down in the logbook. Now, flying fish, what was the 'casion of that 'ere dive?

NATH. There's robbers in the house, and nobody at home but a woman. They locked me up, but the fools

forgot the windows. Will you go up, and take 'em?

TOM. How many strong do they muster?

NATH. Two,- - a man and a woman.

TOM. Do they carry popguns or small-arms? or it's no matter: if they carry small arms, I carry big ones, and here's for action.

NATH. They've locked the door. I'll carry you in through the garden. Follow-softly. (Exeunt.

SCENE 4. A room in ROSLIN'S house (Enter RINGFINGER and GALL.

RING. Bravely done! but tread softly, and despatch.

GALL. Hist! that is her voice: she is singing. 'Twas my money taught her that; and I am likely to be repaid with a workhouse.

RING. Hold your tongue, and think how Ben will pay you, if you miss this chance.-Hush!

EMMA. (Within.) Who is there?

RING. There now! Beware, and despatch. I'Il stand here 
ready.

(Enter EMMA.

EM. I surely heard voices-. Who is this? Oh heaven! What do you here?

GALL. Be silent- oh my daughter!

I will not harm you.

EM. Keep from me, thou wretch!

I am not thy daughter, I thank heaven I am not.

GALL. You are, you are. What madness thus deludes you?

You are my child, my only child, my own.

Why did you leave me, and thus throw yourself

Upon the mercy of strangers?

EM. And why did you, that call yourself my mother, Expose and sell me to that beast, that Ravin?

Begone, begone!

GALL. 'Tis false; I did not sell you.

'Twas but the prating of a drunken man.

'Twas wine that made him rude,-a drunken madness-

EM. And wine it was

That forced the blessed story from his lips

That you were not my mother, but a wretch, Perhaps, that stole me from my honest parents

For wicked ends. Woman, who are my parents?

Tell me, and I'll forgive your former cruelty, Your sinful practices against my honour:

They shall not punish you: If they be rich, They will reward you with their gold; if poor, With a large recompense of prayers and blessings.

GALL. She is mad, stark mad! Oh that it should come to this!

EM. I am not mad; but often I have thought

That madness had been bliss, since it had kept me From knowledge of the wretch I deemed my mother.

GALL. I have been hard with you, I own with shame; 
But 'twas the common peevishness of age.

Come back with me, and fear my wrath no more.

EM. I will not; no. Why should I? I've no claim Upon your kindness; (I meet kindness here:) And if I had, I fear your treachery. Here I am safe.

GALL. Wilful and froward girl! The world will find your stay another cause: A brave, fine youth, a sweet-lipped libertine, A friend, a keeper! Think of that, poor girl.

EM. Your slanders cannot shake my confidence; And if I leave this house, I seek not yours.

GALL . Obstinate fool! Will you be dragged from hence?

You are my child, and my authority, Sanctioned by law, shall make you mine again.

EM. And there is law for my protection too; Law, since you speak of it, that will enforce The secret of my birth from you, and punish Your practices upon me.

GALL. You speak well And boldly, fool. Here is my law at present: Seize her.

EM. Help! help.

GALL. The bandage on her mouth. (Enter NATHAN and TOM TAFFRAIL.

RING. I'd rather put my lips there, for it is a damned pretty one.

TOM. And yours is a damned ugly one, thief!

NATH- Knock him down-Hurra!

RING. Oh lord!

TOM. Peace, you porpoise, while I belay your elbows abaft with this here bit of logline. 
RING. O gadswogs! am I caught at last!

TOM. Gadswogs! That's a word never came from a Christian dictionary.-Stop the old damsel there.

NATH. Stop, you old thief! She is as strong as a bulldog. Hurra! here comes relief! (Enter ROSLIN.

ROS. How now! what's this? who are these?

EM. Oh sir, that is the woman calls me daughter. She, with that villain, would have forced me off; But this brave man, (I know not who he is,) And this good boy-.

TOM. Lie still, you gadswogs fool! till I finish the job, and consider yourself under arrest.

ROS. A thousand thanks, my brave and honest friend.

TOM. If you be the captain of the watch, or the landlord of this here house, I can certify this knave to be a pirate; for he has run a black paint over his phys'nomy, like an unlawful cruiser: and it's my notion that he be sopped in the nearest horsepond, which will wash his face, and show a body what name he sails under.

ROS. Will you help secure them?-I wish to keep them in this house awhile. Nathan, show the way. Separate them.

NATH. Humph! I suppose I am to be made jailor too! —Get along, you sneaking rapscallion! Who's gagged now, you rascal? I am half minded to kick you.

(Exeunt NATHAN, TOM, GALL, and RING.

EM. Sir, I can never sufficiently show my gratitude for your kindness and protection. But, if you would bind me more than ever, now, while that unhappy woman is in your power, oblige her to tell me of my parents.

ROS. Be assured of my endeavours. Did you know her accomplice?

EM. I did; I knew his voice. I have seen him a thousand 
times, and have reason to think him a brother, or some near connection of Mr. Ravin.

ROS. Ha! then the scheme is evident. If I should take advantage of the villain, it would be laid to cowardice. He must escape. But the woman?

\section{EM. Sir!-}

ROS. Be assured I will omit nothing that may be serviceable. But it may not be long in my power to befriend you. I must shortly leave the city: my return is uncertain.

EM. Leave the city!

ROS. It is unavoidable. I may not be able to unravel the secret of your birth before I go.--(Aside.) It shall be told me by that villain, Ravin, or I shall not live to hear it from another.

EM. Return uncertain!

ROS. I would not leave you friendless to the world, and exposed to the machinations of ruffians. I shall depute some proper persons to befriend you: but lest they should not be as zealous as myself,--take these bills. They will secure you advice and assistance of lawyers; they will buy you friends; they will secure you from want.

EM. That I am friendless and unfortunate, Exposed to danger and to contumely, It is heaven's will, and I should not repine. My grief is deeper than misfortune brings: I bear an odious and suspected name; Which gives to calumny the show of truth,, Excuses those who hate me, and constrains The kinder to desert me and forget me. I did delude myself (for I am yet Foolish and ignorant) that all would not Misdoubt me, or, like many, misinterpret My wrongs and sorrows to make crimes of them: I was deceived.-I thank you, much I thank you

For that you have done, for that you would have 
done.

Your gold I need not.

ROS. By my soul, you wrong me.

I think, I know, ye innocent and blameless.

Fair fountains bubble from the foullest fens;

And though the source ye come from be most foul, The offspring is most pure: if it be not,

There is more shrewd hypocrisy upon

Your face, your accents, and within your eyes, Than ever decked Iscariot's countenance.

Shrink not from me: If this discourse be strange, Make it not, by mistaking it, offensive.

There was a time,--your friends were many then; You held me such:-and when detraction turned

Their love to scorn, I grieved, but could not hate.

EM. I am sure

You would not mock me; but these words do not Become your kindness.

ROS. Let me show my kindness:

It may be for the last time I shall see you.

Take these and be removed from danger.

EM. You shall not need to leave your dwelling, sir; I will not trouble you more.

ROS. Mistaken again.

It is your presence makes the house a heaven.

Hear it; hear me confess myself.

Foolish or mad. Unknown, mysterious, Slandered, suspected though ye be, I love ye;

If ye be innocent, as I swear ye are,

Will marry you; if not, I had rather I

Had ta'en a viper to my heart, than e'er

Have seen you.

EM. Shame not a shining reputation

By words like these. Think of me as I am,

Base, lowly, needy.

ROS. Lowly and needy be it, but not base.

Think of ye as ye are? I do, I do;

Ye are a gem, drawn from a worthless soil, Which your rich lustre makes invaluable; 
An ingot of heaven's pure ore, innocence, Tried in the furnace of men's evil thoughts, And still most pure and heavenly: Were ye not, 'Tis not the enchantment of external charms Could move me to this wildness.

EM. This is a folly, sir, unworthy of you. If for your mirth you speak thus, 'tis not well Nor generous; if serious, I must weep That I'm the unhappy cause. Sir, drive me forth From this asylum. There may some be found To shelter me, and rid you of a burden. (Exit.

ROS. I have heard

Of witchcraft that has rational things transformed To beasts and reptiles; of charms that make men love, And clothe some horrible deformity In angel's shape, which they fall down and worship.

I have lost the reason which once guided me, The pride that made me delicate of honour; And, like the fool, that, moved with its bright colours,

Drew forth a venomous serpent from its den, And laid the glittering monster on his breast, Would take this strange sweet creature to my bosom,

Perhaps to sting, to torture, and destroy me. (Exit.

SCENE 1. A room in a tavern.

(Enter RALEIGH, SR. and O'SLASH.

RAL.SR. We are now, O'Slash, in the very town that witnesses the young rake-hell's extravagance; we shall be eye-witnesses, incog., of his vagabond tricks. I warrant me, he leaves sore noses and heavy pockets wherever he goes; for the boy is as free with his fingers as his money.

O'SL. Faith, your honour, but I think the child is a man, and considers himself as well qualified to take care of himself as another, though that other be his 
father.

RAL. SR. He is a fool, and you are another. Ever since his little sister was drowned, rest her soul! I have resolved that Ned, my only child sha'n't be lost for want of overlooking. Look you, O'Slash, he played the very devil at college, for all 'twas in a Yankee land. The wenches went mad for him.

O'SL. Then he did but follow after the steps of his father; and I have heard the wenches went mad for him.

RAL.SR. Fy! thou naturalized ass! Count not to me the sins of my youth.

O'SL. Had your honour but bestowed half this watchfulness upon Mr. Benjamin Garket, the beast!

RAL.SR. If I had, O'Slash, I should before this have had the satisfaction of seeing him hanged on the highest tree in Virginia. I live in hopes of him yet; for a more presumptuous, impudent, extravagant and ungrateful rascal I have never set eyes on. Well, what do you want, young man? (Enter a waiter.

WAIT. Letters for you, sir, if you are Mr. Raleigh of Virginia. (Exit.

RAL.SR. Who told him that?

O'SL. The nagurs doubtless.

RAL.SR. I desired to travel incog., sirrah.

O'SL. With sax nagurs in black and red uniform, dear? That was to vain-glory over the p'aceable quakers, and the 'mancipation societies.

RAL.SR. Humph. My friend-postmaster-hearing from your servant-in town-doing a service-honour of calling. Very much obliged. A letter enclosed.-Don't know the hand-humph. (Reads.) Dear Sir: A person whom 1 
have great reason to suspect is-The devil!

O'SL. He doesn't say so, honey? the devil?

RAL.SR. Benjamin Garket!-

O'SL. Och! only his oldest son. News of him, honey?

RAL.SR. Has been at my house; where he had the insolence to assume your name-oh Lord! and make pretensions to my daughter. A suitable messenger by calling at my house will receive directions where to find him. Jonathan Headstrong. What do you think of that?

O'SL. Luck! luck! Didn't I say it? didn't I swear it? I knew he never crossed the seas. Come away, honey, and let's take him.

RAL.SR. A vulgar saw says, Never count your chickens before they are hatched.-Caution, caution.

O'SL. That for caution, jewel. He's no chicken, but a full fledged fox; and your cautions, and traps, and t'other things are no more to him nor bread and butter and praties. Take him by vi et arms and legs; and when we've catched him,-

RAL.SR. We'll hang him.

(Exeunt.

SCENE 2. A room in GALL'S house. (Enter RAVIN.

RAV. They are not yet returned. If they should fail, if they should be detected my ruin is sure. Neither of them can I trust. The old beldam hates me, and would as gladly see me hanged as the girl violated; and my brother is faithful, not from love, but necessity: make it his interest, and he would as soon barter away my life as a dog's. - Relationship in villany makes men forgetful of relationship in blood.-Ha! who comes there? (Enter RINGFINGER. 
RING. A fox, but without a scent; or if the hounds follow, they give no cry. Come, leg-bail's the word, and damn all penitentiaries.

RAV. Where's the hag? where's Emma? Have ye no-

RING. No: spare your breath,-you'll want it for running. All's blown; old Gall's a prisoner, locked up in Roslin's house till tomorrow, when they'll have her before a squire. They locked me too, but I cut their acquaintance, for I disliked it damnably. Come, douse kitt, and run. We'll have the bull-dogs here in a twinkling, head ratcatchers and all. Come, why don't you stir?

RAV. Why look ye, Jack, I have some designs to accomplish; and I am so bent upon them, that if the very devil, with a halter in one hand and a brandingiron in the other, stood in my way, I would not move. I have never before taken leave of a friend without giving him some reason to lament my departure; and, though fortune frowns on me, I will not do it now. I loved that girl, Jack, - - better, better than my own soul; and if it had been my fortune to have known her sooner, I might not have been the knave and outcast I am. I never thought I was bloodthirsty before; but men do not know themselves till they have gone a course through all the passions and watched the effect of each upon their souls.

RING. You don't mean to stay and fight Roslin?

RAV. Don't I? Damn him.-He has snatched from me an angel, that was breathing compunction and virtue over my heart. I knew not her value, when I thought her completely in my power; I thought I prized her for her wealth: I deceived myself. I will stay. To-

morrow the meeting takes place; and tomorrow I will be revenged.

RING. You will be blown before tomorrow. Decamp's the word. 
RAV. I am easy; I fear nothing,- - neither should you. Gall, for her own sake, will be silent; and she knows nothing of the Domestics. I will impart to you the secret of the girl's birth. If I am killed, or imprisoned, you may sell the secret; her father will pay well for it.

But now, Jack, do you honestly think I may take you to the field as my surgeon? have you skill enough to lug a bullet out of a man's flesh?

RING. Why not? You know I was to be made a doctor. I have heard professors talk learnedly in a lecture room a whole winter through, have caricatured them on the wall, and lampooned them in my note-book, and am therefore as well prepared to look on death as doctors in general. But I am afraid to stay; I am afraid of this young Raleigh.

RAV. Fear nothing. If you do, keep close till the morning, and look over my pistols.

RING. Where are you going to night?

RAV. To Headstrong's. Don't shake your head. I want amusement, action! I have roused an adventurous devil in me, and must put myself in the way of mischief.

RING. You have no hopes there; and if you had, matrimony takes time. Diana-

RAV. Damn Diana. I always hated her extremely; and ever since she fell in love with young Raleigh, I abhor her. I must be even with the bitter fool, and laugh at her. And I must be even with her cousin too:-Come, let's look over my pistols.

(Exeunt.

SCENE 3. A room in ROSLIN'S house.

(Enter ROSLIN and EMMA.

EM. Sir, cannot the law make her speak?

ROS. The law! She still obstinately persists that you

are

her child; and you have no counter evidence, except 
that of a natural abhorrence not apt to exist in a child against a parent; and, I fear me, the law would consider that so slight an argument, as that you should be put into her hands again.

EM. Never, sir. Mr. Ravin,-can he not-

ROS. Mr. Ravin is interested in her claims; and can readily excuse any apparent hints he may have thrown out, under the plea of intoxication. Much evil might result from carrying her before a magistrate. I will detain her till the morrow, and then put the investigation into other hands; for tomorrow I-I leave town. I have in my hand a communication to my beloved mother, which will secure you her assistance and protection.

EM. I have no power to thank you. I hope you will soon return.

ROS. That is doubtful; it rests with yourself.

EM. With me!

ROS. With you. It rests with yourself whether you will secure a friend more zealous and serviceable than another can be. I am rich, and as powerful as wealth can make a man. I love you, and by honourable marriage, would afford you honourable protection.

EM. And I am poor, without either friends or interest; and yet I would not for the world take advantage of the delusion, the mistaken generosity of any one. I am proud too, and will not give occasion to say that I suffered a suspected name to be matched with honour, or sought to bury my disgrace in an ambitious connexion.

(Exit.

ROS. Noble-hearted girl! Every word she says makes me more her slave; and the more I love her, the more I hate the villain that would have wronged her. (Enter HEADSTRONG.

HEAD. Good evening, nephew. 
ROS. My dear uncle, I am glad to see you, very glad. How does my fair cousin? I hear she is as much besieged with lovers, as a vacant sheriffship with candidates. How is it?

HEAD. Truly there is no lack of admirers, when a woman's pocket is as well furnished as her face. But tell me, nephew: there is one, a prepossesing, impudent rogue, that calls himself Edward Raleigh of Virginia, whom I have reason to suppose an impostor.

ROS. And you come to me for his character? Poor Ned! Sir, be he impostor or not, he is my very particular friend, was my chum at Hartford, comes to see me everyday, and has told me all about the affair of your suspicions from beginning to end.

HEAD. He told you? Why how did he know?

ROS. By witchcraft, I suppose. Come, uncle, you have been grossly gulled, to say the least of it.

HEAD. I begin to feel I have. Yet what could make Mr. Ravin suspicious?

ROS. Honesty, sir, honesty-a desire to do you a service, even at the peril of his own neck; for I promise you, Raleigh is a hot-headed fellow.

HEAD. I perceive we were both very foolish; and II have written to his father hinting that Garket may be found in Philadelphia, - - and I suppose we shall have the old gentleman come roaring up here like a hurricane! What an ass I shall appear in his eyes!

ROS. I hope the old gentleman may come, and conclude matters at once; for, to speak seriously, uncle, I know no one I would sooner select as a husband for Diana than Ned Raleigh.

HEAD. And I know no one whose recommendation I would have sooner taken, a month ago, than my sister's son's. 
ROS. A month ago! What, uncle, won't my word wear a month?

HEAD. As we never heed a thief's recommendation of

an honest man, so we never value a libertine's praise of a lover.

ROS. A libertine! Faith, uncle, I believe some one has been as free with my character as with Raleigh's.

HEAD. I am not apt to be meddlesome in the frolics of young men; but, as the brother of your mother, young man, I must say, I think it exceedingly improper in you to bring a mistress into your mother's house.

ROS. Furies! old man, you know not what you say. A mistress! ha, ha! You are merry, uncle.

HEAD. I am serious, sir.

ROS. Then, sir, seriously let me advise you to beware how you repeat all the lying slanders you hear of people you don't know.

HEAD. I hope it is slander with all my heart.

ROS. Sir, it is; you shall soon be convinced of it. Do me the favour to take charge of these papers. They have reference to the object of your suspicions. - I go out of town tomorrow. If I should not return before my mother arrives, give her this, and read the other, which is meant for yourself, in her presence. They will serve, among other purposes, to convince her as well as every one else, that this mistress is as pure in body and soul as your own daughter.

HEAD. I am obliged to you for the comparison, and hope, for your sake, as well as my daughter's, that the object of my suspicions may turn out to be some travelling angel.

(Exit.

ROS. And this is the lot which I have chosen for myself, 
to adore that which every one else thinks worthy to be despised! But it does not weaken my passion. Slanders upon those we love may grieve our souls, but they cannot lessen our affection. (Exit.

SCENE 4. A room in GALL'S house.

(Enter RAVIN and RINGFINGER.

RING. Old Gall, you say, a Yankee?

RAV. Ay; she was a strapping serving lass at the boarding-school where I was educated, from which she was dismissed for loose behaviour. She went South, ingratiated herself with the old fellow, and was in his employ when she and the infant suddenly vanished. -These rags are not half greased.

RING. Well, and what then?

RAV. It was supposed they were drowned, some of their garments being found on the river. Six months ago I recognized the redoubtable devil in the person of a modest matron, who kept a house for the entertainment of loving strangers. I terrified her into compliance with my plans; made her withdraw Emma from the boarding-school where she had been bred, and retire with her to this house; where she has remained ever since, the humblest though not the faithfullest of slaves.

RING. The old devil! and do you know why she stole the girl, and why she was educating her?

ROS. Perfectly well. I thwarted her in that, for which I deserve to be praised; but I thwarted myself in my own designs, for which I deserve to be hanged.

RING. 'Twas all of brandy, Ben, I have told you a hundred times, professors of our calling should beware of strong drink and women. They always betray us: a man in love will make a confidant of his mistress; and a man in liquor will make a confidant of any body. 
RAV. Damn your aphorisms. Here, put these bullets away. I will hit the fellow on the forehead, and try whether his brain's as easily fuddled as my own. And now for Diana.

(Exit.

RING. If he wasn't so susceptible to the tender passion, he would make the most perfect man of business in the world. This week he has done nothing, and the business suffers, - - a business too that's as profitable as the building of Greek frigates, and quite as honest. Well, l'll try my luck with some of the New Twenties. People catch at 'em, and the fools haven't even advertised the plate.

(Exit.

SCENE 5. A room in ROSLIN'S house. (Enter NATHAN.

NATH. I can't stand it much longer. They won't laugh; their faces grow two or three inches longer every day; and if this kind of growing goes on much longer, we shall soon see their chins trailing on the ground, and

their toes peeping out where their teeth ought to be. (Enter RALEIGH, JR.

RAL.JR. Where's your master, boy?

NATH. In my pocket. I was just asking him what fortune wits made in this world; and he answered, Poverty and enemies. There's his word for it.

RAL.JR. "Plays by Wm. Congreve." Sirrah, I asked you for your master.

NATH. And Wm. Congreve is the only master I own in the world. People say Shakespeare is the great master, because he rouses the feelings. Now one who has been kicked into and through the world as carelessly as myself, has no feelings at all.-Cir, if you mean my patron (I hate the word, for it signifies a charitable ass that gives money to a man of genius for the privilege to ride straddle of his back down to posterity;) 
if you mean Mr. Roslin, he is at home.

RAL.JR. Where?

NATH. Talking with—Bah! it like to have been out.

RAL.JR. Out with it. Talking with his—his dear friend, the pretty damsel.

NATH. You may say that; and I can't help telling you it is very foolish to be in love. I can see no pleasure in

it

but the kissing; and if one is fond of that, it is

better to

go to a looking glass, and kiss one's own face, for every

body likes his own face better than any body else's.

RAL.JR. Ha, ha! that's an idea! Well, does Mr. Roslin love this girl heartily?

NATH. Sir, she has ruined him.

RAL.JR. Ruined him! How ?

NATH. She has taken away his spirits to that degree, that the drollest thing one can say is as much lost on him as a fine song on a Quaker, or a tailor's bill on a dandy. When he does laugh, it sounds like a funeral anthem sung under a tombstone; he smiles on one side of the mouth, and grins on the other; and when he wants to look in a good humour, he makes as many wry faces as a crab on a gridiron, or a young lady taking assafedity. Oh, he is so stupid! and so is Miss Emma. They do nothing but sigh; and I hate sighing. I wish he would marry her, and(Enter ROSLIN.

RAL.JR. Marry her! ha, ha, ha! So, brother melancholy. This little oracle has been making free with you, and advising what you should do with thisthis-faith, I meant this beautiful flower, this mushroom that has so suddenly grown out of your heart, and being one day turned into a puffball, will, at the slightest touch, vanish into dust and ashes. 
ROS. Peace, sir; and you, sirrah, I have cautioned you against speaking on this subject.

RAL.JR. Pr'ythee, don't scold my little Solomon: 'twas all my fault. (Exit NATHAN.) Zooks, sir! you are as solemn as a snapping-turtle of a cold day; your face is as awfully expressive as the Newgate Calendar; methinks 'tis like an Egyptian antiquity, or a Greek

monument written over with tragical histories in love. Methinks too I can read in it the history of Paris, that unhappy fool, who, with the choice of any woman in the world, contented himself with a woman no better than she should be. Do you know any such modern couple? any infatuated gentleman that has preferred a-

ROS. Hark you, Ned; you are welcome to vent your wit upon me; spend it lavishly, and if I cannot take it humourously, I will at least bear it patiently. But I cannot suffer sneers to be directed against a being, who has no crimes but her misfortunes, no errors but her griefs.

RAL.JR. Fiddlesticks! the bawd's daughter! Will you let me see her? I have an admirable knack at smelling out female hypocrisy. I was always fond of the sex, and like the gallants of the day, feel myself wiser in their company than in men's.

ROS. In one word, sir, I will put a stop to your sarcasms. This woman is not this girl's parent.

RAL.JR. Who told you so?

ROS. She herself.

RAL.JR. Ha, ha, ha! and are you the ass to believe her? Why she will tell you a thousand other such secrets, if she finds them agreeable to you. she will tell you, she is of noble descent perhaps, irregularly derived from his wicked majesty, George IV., or perhaps from Buonaparte; or perhaps she will go higher, and swear 
she is the daughter of-Venus herself! and fond of her mother's occupation! Pray let me see her: I will so rattle common sense into her ears.

ROS. Sir, if you would avoid giving me mortal offense, say not a word more of her. Speak to me of tomorrow.

RAL.JR. Tomorrow! 'sblood! what a spectacle for tomorrow! Two merchants fighting for the possession of a pearl with so big a flaw in it, 'tisn't half so valuable as the rotten oyster that yielded it; two dogs quarreling for a bone fit to turn a well bred stomach. If you had but some decent thing to fight about! Sir, I sometimes hope you may be killed tomorrow; it would be an early end to a disgraceful passion.

ROS. And, sir, I would rather have your wish accomplished than hear more of this conversation.

RAL.JR. Well, well-what I have said was the duty of a friend and an honest man. I came to see how your spirits were disposed for the rencounter, and to bid you hold yourself in readiness early in the morning.

ROS. I have completed my arrangements.

RAL.JR. I met old Headstrong near your door. He apologized,-_invited me to his house this evening, and I want you to go along. Civility or affection demands a parting.

ROS. I am engaged for the evening.

RAL.JR. Humph! with this little she devil again! Goodbye. - of all the fools in this world, a woman's fool is the most lamentable and ridiculous! (Exeunt.

SCENE 6. A room in HEADSTRONG S house. (Enter RAVIN and a servant.

SERV. Miss Headstrong will wait upon you in a moment, sir.

(Exit. 
RAV. So! had the fates spared me but another week before this cussed cousin of mine made his appearance, I shouldn't have been left to kick my heels together, while the mistress of the mansion was preparing for her levee.- If I didn't know that Roslin was both a brave and an honourable fool, I should fear his story of Emma and that infernal cogniac had undermined me more than even Raleigh's impudence and good looks. But be it as it may, I will have one more snap-and-snarl with her; faith! but I will take infinite pleasure in quizzing her, till she grows as testy, and sputters as much as a green hickory log on a hot fire. - My dear Miss Headstrong!

(Enter DIANA.

DIAN. Be seated, sir.

RAV. Humph! as embarrassed as the beginning of a love scene, and as dignified as the first paragraph of a sermon.-It is long, Miss Diana, since I have enjoyed the pleasure of your company alone.

DIAN. You should not have enjoyed it at this time, sir, but that I meant it for the last, and desired to express my contempt of your unhandsome behaviour.

RAV. Unhandsome behaviour, madam! You surprise me!

DIAN. Was it manly, sir, to take advantage of my father's credulity, and make him behave uncivilly and ungratefully to the preserver of his daughter?

RAV. (Aside.) Well, my arm wasn't hurt, that's a comfort!- Have a care, madam, that your concern in this case does not spring rather from regard to the preserver than the father. Express it thus: Was it not unmanly in Mr. Ravin to have me deprived of the pleasure of Mr. Raleigh's company?

DIAN. And if that be part of my meaning, sir, as I freely confess it was,- - does that make your conduct more excusable?

RAV. Most certainly: Jealousy makes fools and scoundrels of us all; and it is wonderful what silly and scandalous tricks lovers will make use of to rid 
themselves of a rival._-Madam, let me be serious. There was a time when I flattered myself my attentions were not indifferent to you; and that your father's approbation found no opposition in yourself.

DIAN. There was a time, sir, when my father's approbation of any one was a sufficient passport to my esteem.

RAV. I deceived myself with the hope that I was received upon a better footing than that of esteem.

DIAN. The deception then was the more pardonable since it originated with yourself. I esteemed and received you as a gentleman and my father's friend; and was satisfied with your attentions because there

was nothing in them either hateful or improper. With greater intimacy than this I am not able to tax my memory.

RAV. Your memory, I fear, is in this case subservient to your inclination. Be candid, madam, and tell me that this upstart Virginian has effected a change in your heart; tell me this, madam, that I may be able to record in the chronicles of female levity, one more proof of inconstancy.

DIAN. If it be a proof of levity or inconstancy to prefer an open and noble spirit to a cunning and slanderous one, my confession is at your service: do with it as you will.

RAV. You add insult to injury. But I have the means of redress; let your minion beware me.

DIAN. And, sir, do you beware of him! and thank me that he has not already devised a proper reward for your insolence.

RAV. Insolence, madam! Ha, ha! does he regard my suspicions as insolent, and excuse himself from rewarding them under the fear of his lady's displeasure? Why this is excellent! henceforth, let a lover play the 
coward, his mistress will smile upon him for the compliment!

DIAN. Be assured, sir, that I repent very heartily of my interference, and in all future differences will suffer Mr. Raleigh to take his own course. (Exit.

RAV. Ha, ha! Now will she request the lad to horsewhip me, there's no doubt of it! Faith, her anger has put me into a good humour.

(Enter HEADSTRONG.

HEAD. Good evening, Mr. Ravin, I am glad to see you.

RAV. Your servant. Upon my soul, Mr. Headstrong, this fellow has run away with Diana's heart and soul, and if you don't lock her up, he'll run away with her body too. She has been scolding me scurvily, and commending the scoundrel to my Face.

HEAD. Which scoundrel, sir?

RAV. Which! why this knave that calls himself Edward Raleigh, son-

HEAD. He is neither knave nor scoundrel, sir, as I am well informed, but precisely the man he calls himself; and I begin to feel that we have played the fool pitifullv.

RAV. Humph!

HEAD. What, in the name of all that's rational, put such a conceit into your head?

RAV. Faith, I hardly know. Notions sometimes get into men's heads, like frogs into limestone rocks and beetles into oak trees; philosophy can't tell how nor why.-I was curious to hear something of his famous cousin, Garket the swindler: he himself is the cause of what followed, for if he hadn't fallen into such a rage, and decamped so suspiciously, I shouldn't have been so sure of it.

HEAD. You must beg his pardon: you have wronged him. 
RAV. He has wronged me; he has robbed me of your daughter's affections. Before he came with his impudent round face and long rattling tongue, I had every reason in the world to suppose she returned my passion; and to night she railed at me like a dog. Sir, I would rather have a beating than such a scolding, and especially for the sake of such a doubtful fellow.

HEAD. I tell you, sir, there is nothing doubtful about Mr. Raleigh. He is an old friend of my nephew Roslin, who has satisfied me of his character.

RAV. (Aside.) This Roslin is my evil genius; he crosses me every way: But tomorrow settles all._-Sir, I am happy to hear the gentleman is a gentleman; for I should hate to be supplanted in your daughter's affections by a lowbred fellow.

HEAD. My daughter is in no danger of falling in love with a lowbred fellow; and if she has an inclination for Mr. Raleigh, I hope your philosophy will cure your disappointment.

RAV. I hope it will.-The wind changes, and so does man's good will.

HEAD. Look you, Mr. Ravin, nothing would have pleased me better than to see you the husband of my daughter; but I am not, in cool moments, the man to adopt violence when persuasion fails, and to make my own gratification the cause of my child's misery. She loves you not. she is too high-spirited to be forced, and I love her too well to tyrannise.

RAV. Well, sir, I have only to thank you for your many favours, and to take my leave. Tomorrow I return to New England.

HEAD. I hope not so soon. I wish you would stay, and, as a friend, advise with me in the case of young Mr. Raleigh. I expect his father will be in town shortly.

RAV. Ha! his father!

HEAD. I was so foolish as to write to him about this 
affair, and-

RAV. Curse the old fool! Nearly caught in my own trap! I must be off.-Sir, it was very foolish. I cautioned you to leave that matter to me. It was ridiculous.

HEAD. Ridiculous!

RAV. Very.-Unlucky ass that I am, the town's becoming too hot to hold me.-Farewell, sir.

HEAD. Nay, let us not part in anger. You will come once more to see us.

(Enter a servant.

SERV. Mr. Raleigh, sir.

(Enter RALEIGH, JR.

RAV. Death and hell!—oh! 'tis only the cub!

HEAD. Lord, now these two wasps will be at loggerheads.

Call Miss Headstrong hither. (Exit servant.)

Mr. Raleigh, I-

RAL.JR. Sir, I have suffered another man to step before me; but be assured, I will have a word to say to you in time.

RAV. At your service, sir. (Exit.

HEAD. Mr. Raleigh, I must ask your pardon again-

RAL.JR. Let it be forgotten. Here comes one who has already banished all resentment from my mind.

(Enter DIANA.

HEAD. And here comes-Ha! who is this old gentleman? (Enter RALEIGH. SR. and O'SLASH.

RAL.JR. By all that's wonderful, that's pop! Father, your blessing; and, in the name of heaven, what are you doing in Philadelphia?-And Mr. O'Slash too!

RAL. SR. I came here to follow you incog, you rogue. 
I have heard of your doings, sirrah, your harum-scarum, rake-helly doings. Old gentleman, this is my son, Ned, and as proper a son as was ever begotten.

HEAD. If you are his father, sir, I hope, from your present appearance in Philadelphia, that you did not receive a foolish letter I sent you yesterday.

RAL. SR. But I did though; and I have come to find the self same rogue you spoke of.

HEAD. Sir, affairs have changed wonderfully since I wrote that silly letter. That, however, is the man suspected.

RAL. SR. What that? Why that's my son, Ned; and I'Il cane any man that says he has the least resemblance to Benjamin Garket, the Yankee.

DIAN. The Yankee! I thought he was a Southron.

RAL.JR. Father, the delusion is now over. Your hopeful nephew is doubtless in Great Britain or Botany Bay by this time; and you have just come in time to bid me marry this young lady.

RAL.SR. Faith, Ned, she is pretty, - -just what your sister would have been—but she's drowned!

RAL.JR. Sir, you should not think of that unhappy accident; it makes you melancholy.

RAL.SR. I never was melancholy in my life, puppy; nor ever will be till I find Garket has escaped. Old gentleman, what put this notion into your head?

DIAN. What kind of a looking man is Mr. Garket?

RAL.JR. That's more than I can say; I never saw him.

DIAN. Never saw him!

RAL.JR. No; he played his tricks while I was at college.

DIAN. Was he black-haired? 
RAL.JR. So they say; with a sneering, impudent, rascally sort of a face, and a kind of raggamuffin-like gentility about him, said to be exceedingly becoming.

HEAD. And so, sir, I am well convinced how much I have wronged your son, and am willing to repair every thing in a manner which I think will please him, and I hope yourself, by giving him my daughter.

RAL.SR. What! does he like her? Matrimony, sir, is a serious thing, and not to be ventured upon without seeing how the parties agree: And therefore, sir, let me ask you what you think of the Slave System?

RAL.JR. Zounds, father! you are not the parties!

HEAD. I think it a system abhorrent to the general principles of morality and justice, and disgraceful to the character of our country.

RAL.SR. Humph!

RAL.JR. Lord! now for a squabble! Father, I forgot to tell you-

RAL. SR. Stand aside, puppy._-In what light do you look upon the Tariff, Mr. Headstrong?

HEAD. As an excellent encourager and preserver of domestic enterprise:-

RAL.JR. Confound 'em! they'll be at it! Mr. Headstrong-

HEAD. And as the surest and speediest means of creating the same independence in our national economy, which already exists in our national spirit.

RAL. SR. Humph! humph! What opinion do you entertain of the majesty of State Rights, when put in opposition to Congressional supremacy?

RAL.JR. Now for it! Faint, fall into a swoon, Diana.

DIAN. Admirable! Let 'em alone; they argue rarely!

HEAD. I think the majesty of State Rights a very 
ridiculous subject, of which fools of the present day make a bone of contention, and which knaves of a future may make the apple of discord.

RAL.SR. Ned, put on your hat.-Sir, you are an ass. —Start, puppy!—old fellow, I thought your gray hairs smacked of wisdom; but such ignorance, folly, prejudice and political blasphemy, as have this moment come from your lips, I have never before heard uttered by the mouth of man. I would sooner match my son to a squaw or an alligator, than to the heir of such heresy and folly.-Get along, Ned.

RAL.JR. Sir, if you please, I mean to stay and marry this lady.

RAL.SR. Out, you rascal, or I'Il cane you. What! marry such political principles!

RAL.JR. And pray what have political principles to do with my love?

RAL.SR. Out, you rebel!

RAL.JR. Sir, I'll run away with her the first opportunity.

DIAN. Ha, ha, ha! What a merry old gentleman! He'll make a rare father-in-law!

HEAD. Zounds! he is mad!

RAL.SR. Political fanaticism and corruption match with patriotism! Get along with you.

RAL.JR. Father, I don't care a fig for politics and patriotism. I am in love.

RAL.SR. Out of this house, and never enter it more. (Exeunt RAL.SR., RAL.JR., and O'SLASH.

HEAD. Why!

DIAN. Ha, ha, ha! I never saw such an amusing old gentleman; I like him exceedingly, and will give my ten fingers for his good opinion. 
HEAD. He is an old ass, a true Southern political madman; and till I can become a convert to his ridiculous doctrine of slavery and State Rights, will never suffer his son to come near you. I begin to repent we were so precipitate with Mr. Ravin.

DIAN. Mr. Ravin! I hate that man, and, what is more, I suspect him; I suspect him to be a villain, and a very extraordinary one. Black-haired, a sneering, impudentHeavens! father, have you ever seen any of his Yankee relations?

HEAD. No; but he brought letters from the best men in the state.

DIAN. Letters! Letters may be forged!

HEAD. Yes: He is of a rich and influential family, and your folly has lost him to us. He departs tomorrow.

DIAN. Departs tomorrow! When did he determine on t hat?

HEAD. This evening. I told him, I had written to Mr. Raleigh-

DIAN. Did you? What did he say?

HEAD. He was very angry; said it was exposing our folly too far; and then he said he would leave town.

DIAN. After you spoke of your letter? after, or before?

HEAD. After, I believe. What mean all these eager questions?

DIAN. Dearest father, send for him, beg him to call on you tomorrow morning; (Send for old Mr. Raleigh too)—but don't tell him; don't let him know Mr. Raleigh is in town. Oh! if the old gentleman had come a moment sooner!

HEAD. Bless my soul, girl! what's the meaning of all this? Why send for him? 
DIAN. oh, you shall know. Tell him you want to send money by him; but don't send it. Tell him anything to get him here.

HEAD. Well, and when I get him here, what then?

DIAN. Then, if there be substance in woman's wit, or wisdom in woman's penetration, you will find that he who was so good at playing the fool, may be much better at playing the villain! Come along, and I'll tell you all.

HEAD. The villain?

DIAN. Ay, the villain! (Exeunt.

ACT FIVE.

SCENE 1. A room in a tavern.

(Enter, severally, TOM TAFFRAIL, BOLT, and a waiter.

BOLT. Hilloa there, Julep, has any one been for me, yet?

WAITER. No, sir.

BOLT. The Doctor, Mossrose, Crossbar, none?

WAITER. No, sir.

TOM. Gi' me a glass of gin-sling there, shipmate, and a r'ale Havanna.

BOLT. Damn it, can I have no witness?

TOM. A glass of ginsling, I say, friend, and a cigar.

BOLT. Ha! shipmate! wasn't it you that knocked me down in the street t'other night? 
TOM. I never logged it.

BOLT. Dammee, but you logged me though; and ever since my head has felt like a logger head. Come, I know you.

TOM. What was the 'casion?

BOLT. A woman. Come, I harbour no resentment; I deserved all I got. you are an honest fellow, and I want you to do me a service.

TOM. If it be as how there's nothing foul in it, dammed here's for you, timber and tackle.

BOLT. There's a foul villain that picked my pocket in it. That four-pound fist of yours first knocked me into a trance, and then my pocket was picked.

TOM. Look ye here, Mr. What-d'ye-call-'em, you're not the only man that has been run foul of by unlawful cruisers in this here cursedty deceitful town.

There's sharks and sword-fish enough, though they keep their heads under water, to nibble one's eyes out of his head, and run their snouts into one's keel. I have seen a painted pirate run up into a gentleman's head-quarters as naturally as into a Spanish West India harbour; and I've found a counterfeiting knave carry his unlawful paper into a gaming house with as little conscience as a New York speculator sends pewter quarter-dollars to Hayti.-But what has that to do with your pockets? and how am I concerned in the matter?

BOLT. I want you to help me take the cheat.

TOM. With all my heart; and I hope you'll sarve me the same turn. You see this here Twenty; 'tis as fair a looking Twenty as one may look on; but the banks have laid it under embargo, and I am recommended to take the fellow that palmed it on me. I got it at the billiard table of an ugly knave, a cheating land rat, who, I am told is a great lover of this here tavern.

BOLT. You may command my services. But hearken; I only suspect a fellow, and I have a scheme for trying 
him. I learnt it of a New Yorker, who played it with great success on a fellow of the same trade.-Huzza! boys, welcome! (Enter MOSSROSE and CROSSBAR.) This is the good fellow that knocked me down t'other night; but I don't know his name.

TOM. My name's Thomas Taffrail, first officer of the ship Liz. Lucky, and damned lucky she is, old Liz.

BOLT. Which of you saw me last when I was on the pavement?

MOSS. I; I went for a hack, and left the doctor with you.

BOLT. I suspect the doctor of picking my pocket when you were gone, and fobbing me of my patent lever.

MOSS. and CROSS . You don't say so! the doctor!

BOLT. Ay. I believe he is but a wolf. Damn him, I thought he was a vulgar fellow, for all Ravin introduced him; and I was always ashamed of his company, he looks so cursed shabby. Come up stairs, and I'll tell you my plan._-Julep, when the doctor comes, swear I am alone, mind you, alone! (Exeunt.

SCENE 2. Another room in the same.

(Enter the same.

BOLT. I tell you, he is a scurvy fellow. My pocket was picked and my fob emptied, as I lay under his keeping; so there's no harm in trying the rascal.-_Some one lend me his watch.—I am provided with a pocket book and cash all marked. So-Get you to the closets, and be quiet.

WAIT. The doctor is come.

\section{(Enter WAITER}

BOLT. Ensconce! quick! ( Whey conceal.) Did you say Alone?

WAIT. Yes sir, alone. 
BOLT. Show him up. (Exit WAITER.) Now for a knave taking.-Silence, ye grunting whelps, or you'll spoil all. There! (breaks a wine-glass.) Peace, ye eaves'droppers: I am breaking the glasses and getting horrid drunk; I am going through my degrees. In the first, I shall be wonderful funny and good-natured, and pun vilely, and sing like a hack-driver; in the second, I shall be cursed stupid, and look as solemn as a philosopher-hickup! in the third, as quarrelsome as a Kentucky freeholder; and in the fourth as peaceable and humble as a whiskey-brewer,-hickup. Now I'm in the first.-There, smash! (breaks a glass.) Ha, ha, ha! that was a very funny glass, he couldn't stand on his legs, he was so full of wine. Enter conspirator - (Enter RINGFINGER.) Fol de rod rob (sings) so he said there was nothing like wine. Fol de rol.

RING. Mr. Bolt, how d'ye do?

BOLT. Troubled with the blues, doctor, very blue-ha, ha, ha! Poz, I couldn't get any company, and I am resolved to be drunk, drunk, ye grinning porpoise, extraor'nary drunk.

RING. And have you had no one with you?

BOLT. Yes; there was the dandy and the poet; but they got drunk and complained of dyspepsy; so the dogs had to dose with hickory ashes and go to bed,- - the beasts! to get drunk! lord! what fools men are to get drunk!- - Here soak, you rogue; choice as sunshine. As for me, I have joined the Temperance Society, and I carry Chamber's medicine, and I order cabbage on table, so I never get drunk.-Drink, you porpoise. If you should become cosey, I'll send to the'pothecary for sat aeratis, sat gratis, you dog; it sobers one quicker than pump water, sat gratis.

RING. Ha, ha! you are funny. Here's your health!

TOM. (Aside.) The identical devil that give me the Twenty! 
RING. A bumper to all absent friends.

BOLT. And to all dead ones, doctor; for to die is a solemn thing, and to be much thought of. our time is short; (Pulls out a watch;) it is now ten o'clock, and tomorrow we may be in our graves.

RING. Why! have you found your watch?

BOLT. No, but l've bought a better. Sha'n't be stolen, for, look ye, I keep it in my coat pocket instead of my fob; and nobody would think of looking for one's watch in one's coat pocket, would they?

RING. No, not they-—oh! Temptation!—A cunning conceit that. Your health.

BOLT. Your's heartily. And they sha'n't steal my pocketbook neither; for, ye see, I keep it in my hat, and my hat I keep on my head; and they wouldn't think of taking off my hat to look for it, would they?

RING. Ha, Ha! you are the cunningest fellow.-Spare me, Temptation! I have sworn off.-In your hat! ha, ha! 'Tis a very handsome one-Who made it? (takes it from BOLT'S head.)

BOLT. Shelmerdine. Take care of my pocket-book.

RING. I will: (takes the pocket-book, and restores the hat.) There now; keep it on, and all's safe. Your health.

BOLT. Very well, I thank you; 'twas never better. But I feel a little vertigo. One might think I was drunk, but I a'n't, for you see I don't stagger, and I can walk the crack with any man, only I'm giddy,- - that's all, -not drunk. Falls into

RING. FINGER.' S arms.

RING. Not at all; only vertigo.-What noise was that? I thought I heard a stirring!

BOLT. 'Twas my new watch ticking in my pocket. 
RING. Do you feel it now? (Steals the watch.)

BOLT. Yes, it's going.

RING. What's going?

BOLT. Vertigo. But I'm wondrous sleepy

RING. . I'll take you to bed.

BOLT. First, rascal! I'll take you to the mayor! Appear, witnesses, and view the thief, the pick-pocket!

RING. Lord! gentlemen! what do you mean?

BOLT. Mean, scoundrel! Where's my watches and pocket-books?

TOM. Do you know this here Twenty, my heart? 'Tis sworn to be counterfeit.

RING. O gadswogs!

TOM. Oh ho! Gadswogs again! If this shark isn't the painted privateer, may I never see salt water. You'll not break your arrest the second time, Mr. Gadswogs.

RING. It was only a joke, gentlemen.

BOLT. We'll try that. What, pick pocket, counterfeiter, and housebreaker! That's fourteen years in the penitentiary.

RING. For heaven's sake, not the penitentiary! keep me from penitentiaries and solitary cells, and I'll tell all; I'll inform, I'll turn states-evidence, I'll blow Ben, I'll turn state's-evidence, I'Il-

CROSS. Who's that you'll blow? what's that you'll tell?

BOLT. Come along, thief!

RING. Save me from the penitentiary, and I'll blow Ben, brother Ben; I'll turn state's-evidence,-I'll turn -l'll blow- (Exeunt. 
SCENE 3. A room in HEADSTRONG'S house. (Enter HEADSTRONG and DIANA.

HEAD. I shall grow distracted. You are as bad as Ravin himself in your suspicions.

DIAN. Be it so. There is something more in him than I like, something more in his ridiculous conjectures about Mr. Raleigh, something more in his appearance and conduct than can be well explained. Have you sent for Mr. Raleigh?

HEAD. Yes. You are leading me by the nose, to make another fool of myself.

DIAN. Be patient, sir. If I am wrong this time, I'll never ask my own way again,--that' s till I am married . (Enter a servant.

SERV. Mr. Ravin.

(Exit.

(Enter RAVIN.

DIAN. Sir, I have taken the liberty of sending for you, to ask your pardon for some foolish and uncivil expressions, which I made use of when I saw you last. Would they would come!

RAV. That's because she has a favour to ask, confound her!-_They are forgotten, madam.

HEAD. Pray sit down, Mr. Ravin. The message with which I will trouble you is not yet prepared.-Are they coming?-It is dangerous to send a large sum by mail._-Look out the window-They will never come.- a am sorry to trouble you with it.

RAV. It will not trouble me, sir.-The old ass! that's what Jack calls temptation! Put money into my pocket! Well, the lord knows, I am very trustworthy.

DIAN. . Be easy, sir. 
HEAD. What noise is that?

BOLT. (Within.) Put a constable at the front door and one in the garden.

RAV. Ha! I will see what this uproar means.

DIAN. Stay, sir. Oh! what can it mean. O support me! I faint! |-oh! oh!-

RAV. Fear nothing.-Damn her fainting fits. 'Tis nothing I'll warrant.

(Enter BOLT, TOM, MOSSROSE, CROSSBAR, with RINGFINGER and constables.

BOLT. Ten thousand pardons for this violent intrusion.

— Seize the villain.-Be not alarmed, madam.-

DIAN. Seize who?

BOLT. Humph! I should know that voice; but mum's the word.-Benjamin Garket.

DIAN. I said it!

RAV. Bless my soul! Mr. Bolt, what is the meaning of all this? Do you go a visiting in your degrees?

BOLT. Fellow, I am half minded to kick you for your impudence. Seize him. Mr. Benjamin Garket of Virginia, you will now bid adieu to Mr. Robert Ravin of New Hampshire.

RAV. Gentlemen, what means this ridiculous violence? Unhand me, fellow.

BOLT. Zounds! you carry it well. Do you know this man?

RAV. Certainly: that is-

RING. Your brother Jack Ben,-Jack Garket. Oh Ben, it's all blown, and there's no use in bullywragging any more. 
BOLT. Yes, these are the two loving brothers, - - notorious swindlers, robbers, counterfeiters-

TOM. Witness this here Twenty. And piratical rascals, and-

BOLT. And pick-pockets,- -witnesses in abundance

RAV. Sir, in your ear, I will repay this insolence shortly.

BOLT. Pugh! you knave! and wanted me to be your second! - second to a swindler! Faugh! Come, you must march. Link your arms with your brother, and march.

RAV. My brother! What! does this rascal call himself my brother? and is it from his evidence I am thus infamously insulted?

RING. Ben, you know I am your brother, but now I am turned state's evidence against you.

RAV. Fool, this will not serve you. Come along, and let me see if this lying rogue will repeat his knaveries before a magistrate.

RING. What, Ben, do you disown me? I couldn't help it, no I couldn't. But you'd better confess. I've blown all, all. They've sent for old Gall to witness against you, and when they come to the rollers, and the Twenty plate! Oh lord! that somebody had but hanged me yesterday!

RAV. Humph! How long is this farce to continue?

DIAN. We have another actor in it. Walk in, Mr.Raleigh.

(Enter RALEIGH, SR. RALEIGH, JR. and O'SLASH.

RAV. Ha!

HEAD. That such things should happen in my house!

RAL.SR. Oh you outrageous rascal!-are you caught at last? This is the end of all your rogueries, the 
penitentiary, the penitentiary!

RAV. Oh!

RAL.SR. What, has he soul enough to groan?

RING Any body'd groan, that was going to the penitentlary.

RAV. Sir, have pity on me.

RAL.SR. Pity! Why you are a fool as well as a villain.

RAV. I'll buy your pity. Sir, you once loved me well; you gave me your niece-

RAL.SR. Whom you deserted, you puppy; I gave you an office in a bank, which you robbed, you dog; I gave you credit, which you abused, you scoundrel.

RAV. I confess it all. But save me from ignominy and punishment, and I will repay all a thousand fold.

RAL.SR. What a cowardly puppy you are!

RAV. Use your interest for banishment, not imprisonment, and I will bless your old age with a long lost daughter.

RAL.SR. A daughter! I never had but one, and she was drowned.

RAV. She was not,-—neither she nor her nurse.

RAL.JR. Sir, this fellow will say any thing to screen himself from punishment.

RAL.SR. Get out of my way, puppy.-What of my daughter? What of my girl? speak!

RAV. She lives, sir, and-

RAL.SR. Now if you lie, you wretch, I'll have you hanged, I will. Where is she?

RAV. Her savage nurse ran away with her, educated 
her for, and would have devoted her to the worst of purposes. 'Twas I that saved her from pollution and perdition.

RAL.SR. I'll do all I can for you, you dog. you are an honest fellow at bottom, for all of your knavery.

RAV. I took her from the beldam, I preserved her, I-

RING. Yes, he saved her; I can certify to that; he saved her for himself: and, dang him, we'd all have been as happy as dogs, if he hadn't wanted to be too loving to her.

RAL.JR. Ha! —What a horrible thought!

RAL.SR. Where is she? where is she?

RAL.JR. Ay, where is she, villain? Why do you look so fiercely on me, and smile?

RAV. I was smiling to think what fools you were to rejoice in my story, and what an ass I was to suppose it could benefit me.

RAL.SR. Where is she?

RAV. Why she ran away.

RAL.SR. Ran away! Whither?

RAV. Not far. you will find her by asking of this young man's friend and this old man's nephew, Mr. Roslin, for Emma Gall;-

RAL.JR. Oh God!

RAV. For your daughter is Emma Gall, and Emma Gall is his mistress. Settle it between you.

(Exit RALEIGH, JR.

RAL.SR. Ah! lord! take the arch-devil away; hang him, hang him; I'll petition to have him hanged, hanged, hanged. Oh lord! oh lord! mistress! Would she had been drowned. 
TOM. Old Gentleman, though this tale speaks as straight forward as a log book, I will take it upon me to say the man lies, and the truth isn't in him; and if you'll just loose him for five minutes, and show him fair play, I'll engage to flog him till he confesses himself a liar.

DIAN. Good man, I know you.-Take the wretches away. (Exeunt RAVIN, RING FINGER, BOLT, MOSSROSE, CROSSBAR, and constables.) Be pacified, sir. I'll stake my life that the villain is false, and said this only out of malice. If Emma Gall, that unhappy girl, be your daughter, then I can assert that, six months ago, a more innocent and modest creature never breathed. I'll stake my life she is innocent.

HEAD. Hold! My nephew swore she was as virtuous as my own child; and put these papers into my hand, saying they were proofs of her honesty. This for my own keeping, I will open; the other is directed to his mother. Eh! what's this, a deed of gift to "Emma, commonly called Emma Gall", of-eh! how many thousand?

RAL. SR. A settlement! a settlement! the wages of her infamy! 'tis plain. Would she had been drowned! Would she had been drowned!

DIAN. The other paper, father! break it open, break it open!

RAL. SR. Yes, give me more proof; that I may curse the day she was born.

HEAD. (Reads.) "My beloved mother: An unhappy son begs to recommend to your protection an unfortunate but innocent girl."

DIAN. . There! innocent! I said it.

HEAD. "I loved her, and, though appearances and evil tongues have spoken against her pure fame, would have married her. But her noble spirit, refused to match a suspected name with mine, although this would have rescued her from penury, sorrow and oppression." 
DIAN. There! noble!

HEAD. "I have applied a pittance of my wealth (for she has nothing but her virtue and magnanimity,) to assist her in the search after her parents, whom she has never seen and from whom most probably she was stolen. Assist and protect her, for she is worthy your kindness."

RAL. SR. Huzza! ha, ha, ha! He shall marry her! She is innocent! I knew it, and so did you, and you shall have Ned for saying so; and Ned is a good boy. Come here, Ned, you rogue, and kiss her.

O'SLASH. Faith, but he is gone,- - gone to get an umbrelly, I fancy, to $\mathrm{k}^{\prime}$ ape the tears from falling on his back. Sure, sir, if ye would be after r'ading that same letter again, it would pl'ase me exceedingly, for it is as melancholy as my ould mother's last groan.

TOM. I won't say that, but I will say, he was a damned honest chap that wrote it.

RAL.SR. Where did he go? when did he go.

O'SLASH. Where, honey, I can't tell; but when, when that divil, Garket, spake about Misther Roslin, and she, dear, being his-O the vicious sarpent! I can't spake it.

DIAN. O sirs, come to my cousin's house, quick! Edward is hot-headed, and has not heard all

RAL.SR. Now I'll bet any body a dollar, the rogue has gone to fight, without saying a word about it, for Ned will fight. Quick._-If he kills Roslin, I'll have him hanged, for I intend Roslin shall be my son-in-law. (Exeunt.

SCENE 4. A room in ROSLIN'S house. (Enter ROSLIN and NATHAN.

ROS. 'Tis strange he comes not! 
NATH. Sir, if you can't take me with you, wouldn't you like to hear one more joke before you go? I have been studying half a dozen, and if you choose, I'll write them fair and put them into your trunk, to help the dulness of the steamboat.

ROS. My poor boy, I have lost my relish for jokes. I envy you your spirits and your boyhood. Once I was like yourself.

NATH. Sir, you are not an old man; and if gravity comes as soon and unexpected over youth as a cloud over an American sky, I pray heaven I may be a boy to my dying day.

ROS. Your fate will be one chequered with joy and sorrow. I can read your character and fortunes in after life; they are those of a man of genius. You will neglect the golden chances of life, and for the hope of enjoying a barren reputation, for the sake of praise and fame, you will devote yourself to a profession whose rewards are for the most part poverty and mortification; and sometimes, boy, when I am dead, you will feel I have well predicted your fate.

NATH. When you are dead, sir, I will write your Epitaph. I wrote Miss Emma's this morning. Sir, I sometimes think she and I ought to be brother and sister.

ROS. And why?

NATH. Because she appears to have the same pedigree with myself, and in my mind ought to take the same name.-so, here comes the Virginia gentleman. I like that man, he is so merry. (Enter RALEIGH, JR.

RAL.JR. Begone, boy

NATH. Umph!

(Exit. 
ROS. I have been waiting for you. I have prepared every thing, and now-

RAL.JR. Have you prepared for death?

ROS. A singular question! Come, let us go.

RAL.JR. Stay. Your man is in prison.

ROS. In prison!

RAL.JR. Ay, for a knave that has no equal on Earth. His devil has deserted him. Sir, that man is my cousin the knave, Benjamin Garket; and I wouldn't have you harm my cousin, though he is a knave, ha, ha!

ROS. Then the quarrel is over, thank heaven! and now for a more agreeable duty.

RAL.JR. Stay, sir. There's another lays claim to the combat with you.

ROS. Another!

RAL.JR. Ay. One you have injured beyond forgiveness.

ROS. I have injured no man.

RAL.JR. By heaven, you have;--one that loves you too, and yet will slay you.

ROS. You jest!

RAL.JR. You have dishonoured him, made him and his whole house loathsome to themselves and all, ridiculously loathsome.

ROS. If I have wronged any one it was unconsciously.

RAL.JR. Unconsciously! I know it was. I know you love me, and would not willingly load me with shame and disgrace.

ROS. You!

RAL.JR. Ay, me! your friend! The city rings with it 
already; and I must kill you.

ROS. You are mad!

RAL.JR. Come take it. 'Twas meant for this morning's duty, and will serve your turn. Take your place.

ROS. Heaven bless me, Ned! are your wits gone? or is this but a boyish jest?

RAL.JR. I am serious and rational. Take it and defend yourself.

ROS. He is mad, mad! and dangerous. So, ho! there!

RAL.JR. Peace! I can trifle no longer. Take the weapon, or I will blow you through the head.

ROS. Madman! how have I injured you?

RAL.JR. I'll not blister my tongue, nor shock your ears by speaking how. But you are a villain. Defend yourself.

ROS. Ha! steps on the stairs.-

RAL.JR. Then there is not a moment to be lost. Heaven have mercy on your soul!

(Enter RALEIGH, SR., HEADSTRONG, DIANA, and NATHAN.

RAL.SR. Hold, you fool; give me the pistol, you brawling puppy. Sir, you are a hot-headed fellow, and I am half minded to cane you, I am, you dog. How dare you think of pointing a pistol at a man, without asking my permission, you puppy?-so, he's a pretty fellow, and I like him hugely.- - How dare you, you young rake-hell, point a pistol at my son Ned?

ROS. If you are that madcap's father, I must beg you to keep him out of mischief: He's crazy. 'Sdeath, he was about to shoot me! He talked about injuries, wrongs, dishonour, and so forth, when, on my life, I know less of his meaning than he does himself.

RAL.SR. Sir, you are a base, prevaricating fellow; and 
Ned speaks the truth.

ROS. How, sir!

HEAD. Let me explain.

RAL.SR. Keep dumb, old gentleman. Here, you, I tell you, you look like an exceeding wicked young man. Send directly for that piece of scarlet deviltry you stole from her honest parent, honest old Gall; that painted girl, I say, that wench, that horrible young hypocrite, sir, that-that-

DIAN. Is this old gentleman mad!

RAL.SR. That Emma Gall, that's her name.

ROS. Sir, I believe insanity runs in your family. Whatever interest you may have in this unfortunate girl, I know not; but this I am sure of, every Epithet you have applied to her is excused only by your dotage. How is this, uncle? What means this?

HEAD. It means that you are accused (Stand back, Dy:) of-pooh! Send for the girl here. Bring her, little fellow.

(Exit NATHAN.

ROS. I have already said, and I repeat, that your suspicions are slanders only upon your own good sense; and I must add, this singular visit and ridiculous charge are as unwelcome as meddlesome.

RAL.SR. Hear him! Stand back. (Enter EMMA and NATHAN.) Lord, but she is a sweet looking creature!

NATH. Come on; don't be afraid; they won't eat you.

DIAN. Let me speak to her, father; she is frighted.

HEAD. Peace. Let this old madcap play out his plot.

ROS. Sir, if you intend to take upon you any officiousness, remember it is a woman, a virtuous, delicate and unhappy woman you speak to.

RAL.SR. Oh Ned! look at her! 
EM. Sir, what is the meaning of this? Why am I called before strangers that do not, and acquaintances that will not know me?

ROS. That these old folks will answer. They come, I believe, to vent some silly and unmanly slander; but rest assured that their attempts will only fix you more firmly in my esteem.

RAL.SR. Stand away, you talkative fellow. Here you, you girl (Oh the mouse!) what's your name?

NATH. What an old fool, to talk that way to a pretty young lady!

EM. Alas! I know not, sir.

RAL.SR. I am told it is a devilish bad one, and that this fellow here has been trying to make it worse.

EM. You should not jest with the unhappy.

RAL.SR. You're right: I shall blubber by and by like a teething child. Don't you know it' s a sad thing for a young woman's fame to be found under this fellow's protection? for how can he protect that in another which he has not himself?

EM. I know I am destitute and misunderstood, reproached not only for my misfortunes, but for accepting the kindness of the benevolent.

RAL. SR. How she talks!-But this fellow is a deceiver, a very dragon; the greatest rake, villain, rascal, scoundrel, cut-throat-

EM. Hold, sir. Now I find I was deceived in you. I thought you a kind and just man: you are not.

RAL.SR. The sweet imp! he shall have her, ha, ha, ha!- - How now, mistress! Why he is accused, and he can't deny it, of stealing you from your parents; nay of breaking open the house, knocking down your good old mother, and carrying you off, before she was done crying mercy. 
EM. You are deceived. I see that slander

misinterprets,

The noblest deeds, and of an act that angels

Are proud to witness, will form a tale

That devils shrink abashed from. Hear the truth:

From violence, from the brutality

Of drunkenness, (when she you called my mother,

Scoffed at my cries,) this gentleman rescued me;

And, though suspicion called me low and base,

Cast me not out upon the frowning world,

To roam a beggar and a wretch forever.

I had no friends, no parents, and no home:

He gave them all, offered a home, a parent

In his good mother, and in himself a friend.

If there be fault in this, be mine the blame.

DIAN. It is shameful to trifle with her longer. Emma!

My friend! my sister!

RAL.JR. And mine.-That I should be the dog to suspect her!

RAL.SR. Kiss me, you melancholy thing, kiss your father.

EM. Father!

RAL.SR. Why yes, didn't I tell you before? I thought you was drowned; but it was all a sham of that damned old hag-

EM. Oh sir! and a brother! Am I not in a dream?

ROS. And a lover too, Emma. Are we not all in a dream? Pr'ythee, pinch me, Nathan. Ha, ha, ha! why this is rare! You, sir, her father? you my friend's father, the father of-

RAL.SR. of Emma Raleigh, you dog, no more Emma GALL.

EM. Oh, sir, and my mother! Have I a mother?

O'SLASH. Why look ye, young jewel, you had a mother; but when we were hunting for you, she took it into her head you had gone to heaven; and there she went to 
look after you.

RAL.SR. And wasn't she disappointed though? ha, ha, ha!

ROS. Hark you, Ned, you once wished you had a sister to give me. Shall I have her? You don't value her very high, I know; a pearl with so big a Jaw, - a bone fit to turn a well bred stomach,-ha, ha, ha! Give me your hand; take it, or I'll blow you through the head.

RAL.JR. Curse your reminiscences: I was a fool, and so were you.

HEAD. How many brains are running topsy-turvy now!

NATH. I have seen the like in novels and plays: but that such things should happen in Philadelphia!

RAL . S R. Come here, you jade. Now what are the young fools talking about?

ROS. Of another change of names, my dear sir.

EM. I hardly know how to realize my new condition. But if gratitude to my preserver does not argue ingratitude to my father, I would gladly convince this gentleman, that what Emma Gall could not hear, Emma Raleigh is desirous to grant.

DIAN. And if I may follow a good example, I am ready to hear what this young wretch has got to say. Come, say it, and be quick.

RAL. SR. Send for a parson.

DIAN. For what, sir?

RAL. SR. A parson; and we'll all be married together.

DIAN. But the State's Rights, sir?

RAL.SR. A fig for State's Rights! Send me a parson. 
DIAN. And the tariff?

RAL.SR. May go to the devil. I'll never talk politics again. He shall have you.

DIAN. What, marry such political principles! political fanaticism and corruption! Sooner match my son to e squaw or an alligator. Let me ask you what you think of the Slave System, Mr. Raleigh?

RAL.SR. Take her away, Ned, or she'll set me crazy. Old fellow, a'n't you pleased? and you, you young spider, what's-your-name, a'n't you pleased? you with your mouth open there?

NATH. My name's Nobody, and I am surprised. What, is that young lady your daughter? and is she to be married?

RAL.SR: Yes, all to be married, monkey.

NATH. And what's to become of me? am I to be married too? If I am, I pray you will find me some rich old woman, rich, for it is as ridiculous to match wit with poor beauty, as to tie an eagle to a snappin'-turtle; and old, for by the time she dies and leaves me her money, I shall just be old enough to marry somebody else, and then youth and beauty for my money.Sir, had you never a son stolen away as well as a daughter?

RAL.SR. No.

NATH. Well, well, I shall perhaps find some dull old fellow one day, to father me and my jokes. But this is all very strange; very strange adventures; and when I am a man, I will make 'em into a tragico-comical play; and I think, 'twill succeed, for what Nobody writes, nobody ought to damn.

RAL.JR. Succeed! what will the people think of it?

NATH. Think nothing at all, till they have heard what folks t'other side the water say of it. Nobody has a right here, in such matters to think first and for himself. We're too young a people for that; and our 
modesty says we want judgement, and must form our opinions at second hand.-Well, fun for me, and good luck for all. I desire to congratulate all here, these matrimonial ladies and gentlemen, and especially

Miss Emma, for she has found a father.

Alas for me! no father yet appears,

To call me son, and lug me by the ears;

To find me friends, and buy me a school-master, By rods to make ideas gallop faster;

Where e'er he walked, to bid the people follows And show me for a smart dog, like Apollo.

Shall I go look for him the wide world through? Perhaps he's lurking in the midst of you!

Faith! there's a face I'd almost call his own, 'Cause of its threatning and parental frown, Expressing very clearly to my eye, You mischievous dog, I'll flog you by and by.

And there's another; better still! it smiled! Like a kind father on a pardoned child:

And there's another,-smiling too!—another!

Each one that smiles must be my father's brother:-

My honoured uncles!-Faith! and there's a cousin! How d'e do?-Another! one, two, three, a dozen! Be all relations; and as such, you'll pass A kinder sentence on our Looking Glass. (Exeunt.

FINIS

Page 15. Fip. An abbreviation of fippenny bit=fivepence: a colloquial name formerly common in Pennsylvania and several of the Southern States for the Spanish half-real, the value of which was about six cents.

Page 21. Springes. A springe is a noose or snare for catching small game. 
Page 32. Boggle at. Boggle, to take alarm; start with fright; shy, as a horse.

Page 34. Fobbed. Fob, to rob or to cheat.

Page 67. Jersey comings. Coling is probably a colloquial use of the word, colline, a hill.

Page 69. Bona-roba. A Courtesan; a mistress.

OF this book, there were made by Pynson Printers of New York, four hundred and sixty-five copies for subscription by friends of THE COLOPHON.

In The Month of May,

[Image]

MCM XXX III. 